\title{
Resistance inducers and their role in reinforcing wheat defense system against fungal pathogens
}

\author{
Prem Lal Kashyap ${ }^{1 *}$, Sudheer Kumar ${ }^{1 *}$, Sumit Kumar Aggarwal ${ }^{2}$, Noyonika Kaul ${ }^{1}$, Poonam \\ Jasrotia $^{1}$, Arun Gupta ${ }^{1}$ and Gyanendra Pratap Singh ${ }^{1}$ \\ ${ }^{1}$ ICAR-Indian Institute of Wheat and Barley Research (IIWBR), Karnal, Haryana, 132001, India \\ ${ }^{2}$ ICAR-Indian Institute of Maize Research (IIMR), Ludhiana, Punjab, 141004, India
}

Article history:

Received: 27, Sept., 2021

Revised: 7 Dec., 2021

Accepted: 16 Dec., 2021

\section{Citation:}

Kashyap PL, S Kumar, SK Aggarwal, N Kaul, P Jasrotia, A Gupta and GP Singh. 2021. Resistance inducers and their role in reinforcing wheat defense system against fungal pathogens. Journal of Cereal Research 13(3): 229-254. http://doi.org/10.25174/2582$\underline{2675 / 2022 / 112810}$

\section{*Corresponding author:}

E-mail: Prem.Kashyap@icar.gov.in; plkashyap@ gmail.com; sudheer.icar@gmail.com (c) Society for Advancement of Wheat and Barley Research

\begin{abstract}
Plant resistance inducers $(P R I)$ are considered as a novel and prospective option to manage fungal diseases. They offer an improved plant protection strategy in an environmentally safe and economically sound manner. A galaxy of resistance inducing compounds of different origins have been reported and tested successfully in different plant-pathogen systems. The published literature illustrates that the mechanism of action of PRI molecules differs from other agrochemicals as they protect plants from pathogen via stimulating plant defense machinery. Moreover, resistance inducers can be integrated with biological control agents and even fungicides, which could result in reduced use of agrochemicals in agriculture. A plenty of biological control agents are identified and validated for field usages, but further expansion in product development and their effective deployment in wheat and other disease management will inevitably require in depth knowledge and understanding of multifaceted interactions operating between plant and microbe. The current review offers an overview of PRI's that have been tested in wheat in order to activate its own defense system for attaining durable protection against fungal invasions. Additional attempts have been made to highlight the nature and applications of biological control based on different resistance inducers and their mechanism of action along with contemporary status and future developments with other measures of disease tactics in spatiotemporal manner.
\end{abstract}

Key words:Defense, fungus, ISR, jasmonic acid, rust, SAR, salicylic acid, sustainability, wheat, yield

\section{Introduction}

Wheat (Triticum aestivum L.) is regarded as one of the most vital food crops which provide daily nourishment to a large section of global population. Several reports have indicated that global wheat production would need to be enhanced by $60 \%$ to match the food needs by 2050 (Kumar et al., 2021). This target seems difficult to achieve in light of present scenario of diminishing arable land, scarcity of water resources and unpredictable climatic change (Jasrotia et al., 2018). Moreover, regular invasion of fungal pathogens also causes drastic reduction in the wheat yield as well as on quality seed production (Goyal and Prasad, 2010). The major fungal diseases of wheat include rusts (yellow, brown and black), Karnal bunt, foliar blight, powdery mildew and loose smut (Kumaran $e t$ al., 2021; Khan et al., 2021; Bishnoi et al., 2020; Kashyap et al., 2020a; Gupta et al., 2017; Al-Maaroof et al., 2015; Jindal et al., 2012; Park, 2007; Joshi et al., 2004). Besides this, in literature several other region specific diseases of 
minor significance, for instance, head scab, wheat blast, flag smut, foot rot, hill bunt, viral and bacterial diseases have been documented throughout the globe (Singh et al., 2020; Kashyap et al., 2020b; Mehta et al., 2014). The published reports indicate that diseases alone have the ability to cause $15-20 \%$ yield loss annually, but reports of more than $50 \%$ yield loss in wheat have also been documented (Figueroa et al., 2018; Griffey et al., 1993). To date, systemic and protectant fungicides are widely used for the management of fungal diseases in wheat for maximum harvest (Basandrai et al., 2020; Kumar et al. 2018; Selvakumar et al., 2015; Mahapatra and Das, 2013). Unfortunately, regular and injudicious usages of agrochemicals have resulted in numerous negative impacts including the upsurge in residue levels of agrochemicals, emergence of fungicide-resistant fungal strains and human health hazards (Sharma et al., 2019; Kashyap et al. 2019; Kashyap et al., 2018b; Bruce, 2010). Therefore, induced resistance (IR) could be an alternative approach for improving wheat productivity by avoiding losses caused by biotic stresses.

Advances in research efforts involving IR in plants have resulted in the discovery and identification of new class of chemical inducers with better efficacy, stability and environment benevolent nature in comparison to existing traditional agrochemicals (Yassin et al., 2021; Sandroni et $a l .2020)$. There are several reports that highlight the role of IR compounds in enhancing agricultural productivity by reducing the yield losses and by enhancing the stress tolerance levels (Sandroni et al., 2020; Oliveira et al., 2016). A large number of compounds derived from elicitor molecules (molecules released during the first stage interactions between the plant-pathogens) have been identified (Abdul Malik et al., 2020; Jamiołkowska, 2020; Wiesel et al., 2014; Angelova et al., 2006). Biochemically, elicitors reported as RI compounds represent carbohydrate polymers, glycoproteins and lipids. They are reported to be either synthesized by microorganisms or can be extracted from the cell walls of plant, fungi and bacteria (Sandroni et al. 2020; Abdul Malik et al., 2020, Thakur and Sohal, 2013). S-methylbenzo [1,2,3]thiadiazole-7-carbothiate (acibenzolar-S-methyl) (ASM) was the first molecule released as IR compound at commercial scale for agriculture use (Lyon and Newton, 2007). Later, compounds that resemble the action of salicylic acid (SA) include 2, 6-Dichloroisonicotinic acid
(INA) and ASM have also become available in the market and are currently being used in agriculture (Dewen $t$ al., 2017). The major merit of these compounds is that by using these, the number of sprays of conventional fungicides may be reduced (Sandroni et al., 2020). All the resistance inducers (RIs) have few characteristic features which include their preventive mode of action and augmentation of natural plant defense system. Additionally, they also help in reducing the number and frequency of preventive fungicide applications for the effective and precise management of biotic stresses (Llorens et al., 2017). Usually, the phenomenon of induced resistance is operated throughout the plant cell and is strong enough to safe guard the plants from moderate level of stresses. However, it is important to mention here that, heavy inoculum pressure can breach the natural defenses of the plant (Pagán and García-Arenal, 2018), but under such situation, integrated application of plant resistance inducers (PRIs) with recommended fungicides offer complete protection (Llorens et al., 2017). Further, it has been reported that, an accurate and synchronized schedule of resistance inducing compounds with traditional fungicides offers dual advantages in the form of disease severity and chemical residue reduction (Llorens et al., 2017). Further, published literature also indicates that the integrated application of plant resistance PRI's with fertilizers or beneficial microbes could be a promising preventive and therapeutic option against harmful pathogens (Ons et al., 2020). The amalgamation of PRIs in any disease management modules, either individually or in combination with other conventional disease management tools, could be a trust worthy way for reducing the yield losses as well as chemical residue problems in the environment. In summary, the present article provides an up to date knowledge of resistance inducing compounds that have been successfully tested for safeguarding wheat crop from fungal pathogens by activating the plant's own defense system.

\section{Induced resistance (IR) and its types}

In simple words, induced resistance (IR) can be defined as a physiological state of heightened plant defense where plant's basal defenses activates in robust and prompt manner to circumvent misuse of resources and to curtail tradeoffs between defenses against abiotic and biotic stresses. On the basis of elicitor nature and regulatory 
pathways engaged in the generation of molecules, IR can be divided into induced systemic resistance (ISR) and systemic acquired resistance (SAR) (Durrant and Dong, 2004; van Loon et al., 1998). Several research evidences indicate that microbes of virulent, avirulent and nonpathogenic nature when come in contact with the plant have the ability to activate SAR (Pieterse et al., 2014). Host plant and elicitors are two critical factors and act as determinant factor for deciding the specific time period required for the stimulation and establishment of SAR as a consequence of synthesis of pathogenesis-related (PR) proteins (chitinase and glucanase) and SA (Choudhary and Johri, 2009; Walters et al., 2005). Principally, SAR indicates rise of salicylic acid (SA)-mediated basal resistance, while ISR represents augmentation of jasmonate/ethylene (JA/ ET)-mediated basal resistance (Cortes-Barco et al., 2010). Besides this, the mode of action of ISR also relies on the defense mechanisms triggered by inducing agents. Research evidences also revealed that multiple defense mechanisms expressed in response to ISR stimulation are tightly linked with the rapid production and accumulation of chitinases, peroxidases and $\beta$-1, 3-glucanases (Anand et al., 2007; Maurhofer et al., 1994). Another important trait of ISR includes wide number of pathogens that can be regulated by a single inducing agent (Hoffland et al., 1996). Overall, it seems that ISR triggers as a consequence of multiple mechanisms which operate altogether to provide protection against spectrum of plant pathogens. Both 'induced responses' and 'induced resistance' have been extensively explored, well documented and are reported in wide range of plant species (Puyam et al., 2019; Silva et al., 2018; Alexandersson et al., 2016; Srivastava et al., 2012; Kashyap and Dhiman 2009; Heil and Bostock, 2002; Karban and Baldwin, 1997). The major advantage of PRIs in comparison to agrochemicals is the compatibility of PRIs with biocontrol agents (BCA). Another advantage offered by PRIs is the induced resistance (IR) via priming, which results in an augmentation of basal defense resistance regulated by a series of defense related plant genes (Bruce et al., 2017; Ahmad et al., 2010). Owing to these features, IR provides a durable form of protection, since the augmentation of multigenic resistance is difficult to breach by pathogens (Ahmad et al., 2010; Gardner et al., 1999). Thus, the potential of broad-spectrum disease management using the plant's self-resistance modules has led to amassed motivation in the identification, characterization and development of agents which can mimic and act as natural inducers of resistance.

\section{Resistance inducing compounds and their applications}

The resistance potential of wheat crop against fungal pathogen, infection can be augmented by exogenous treatment of a series of biotic and abiotic inducers (Table 1). Biotic inducers include infection by hemibiotropic pathogens, plant-growth-promoting microbes and treatment with non-pathogens or cell wall fragments (Walters et al., 2013; Kashyap et al., 2017). Another category of abiotic inducers encompasses the chemical compounds that act at innumerable points in the signaling pathways associated with disease resistance as well as other forms of abiotic stresses such as drought, heat shock and pH stress etc. (Walters et al., 2005). Most importantly, resistance triggered by resistance inducer (RI) compounds is broad-spectrum, durable and long lasting (Yassin et al., 2021; Věchet and Šerá et al., 2015).

\subsection{Chemicals and non-biological inducers}

\subsubsection{Chitosan}

Chitosan is discovered by Rouget (1859) and structurally composed of $\beta$-(1-4)-linked d-glucosamine and $\mathrm{N}$-acetyld-glucosamine and randomly present within the polymer. In fungi, chitosan is present in the cell walls of Zygomycetes fungi (Batista et al., 2018; Raafat and Sahl, 2009). The characteristics properties of chitosan include biocompatibility, non-toxicity, low allergenicity and biodegradability. In addition, it is cationic in nature. Several published articles comprehensively portrayed the practical applications of chitosan in plant growth promotion and protection (Maluin and Hussein, 2020; Kashyap et al., 2015). It has been documented that chitosan chelates the essential elements required for the optimal growth of plant pathogens and also deposits on plant and pathogen surface and forms biofilms that results in the deprivation of the nutrient availability for microorganisms and thereby restricting the normal growth of the pathogens (Xing et al., 2015). More interestingly, the characteristics feature of chitosan to induce resistance in plants is tightly associated with its elicitor-like properties, which trigger the early activation of pathogenesis-related proteins and augment the plant resistance. For instance, in case of wheat, application of chitosan provides protection 


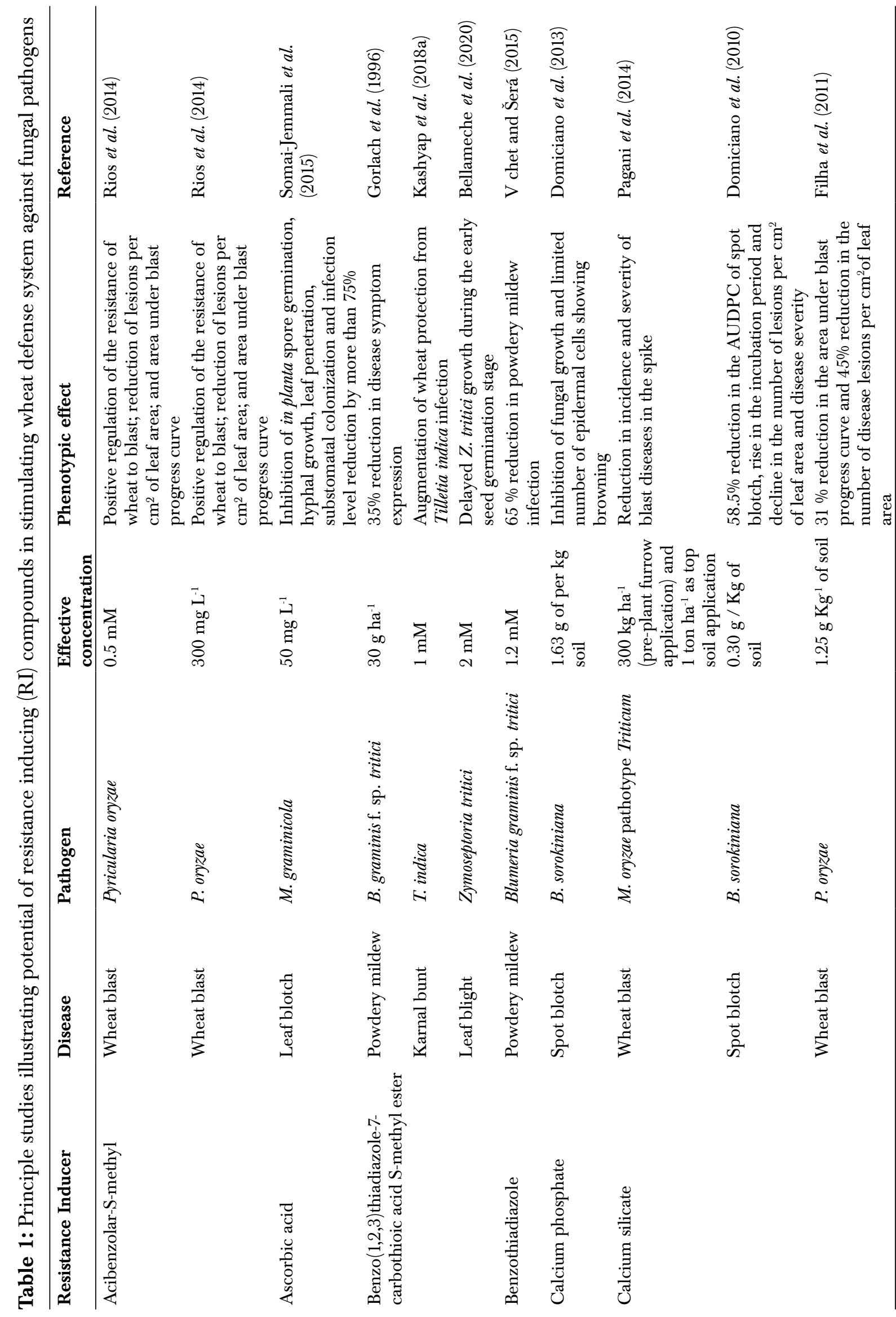


Resistance inducers for wheat protection from fungal pathogens

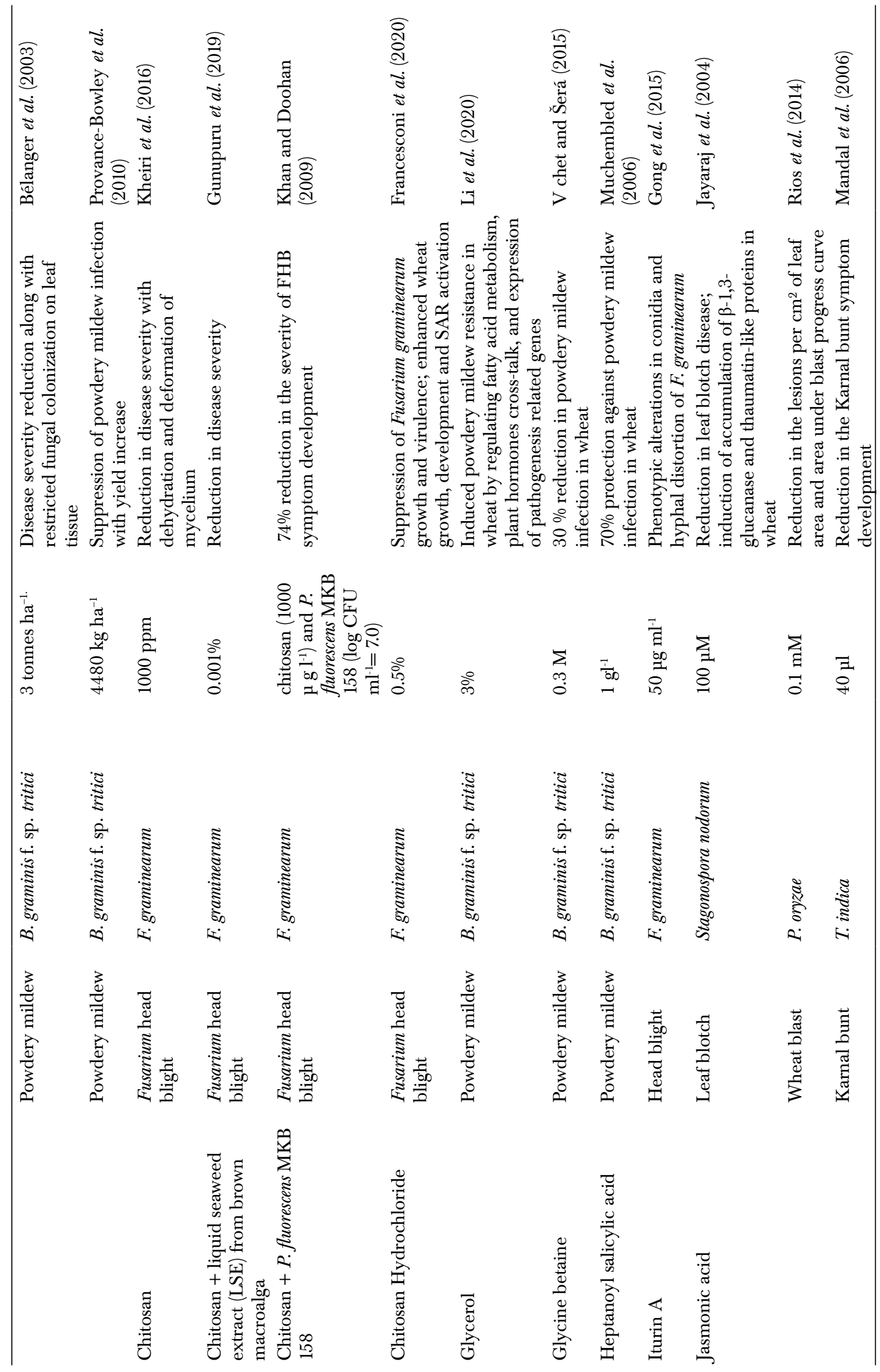




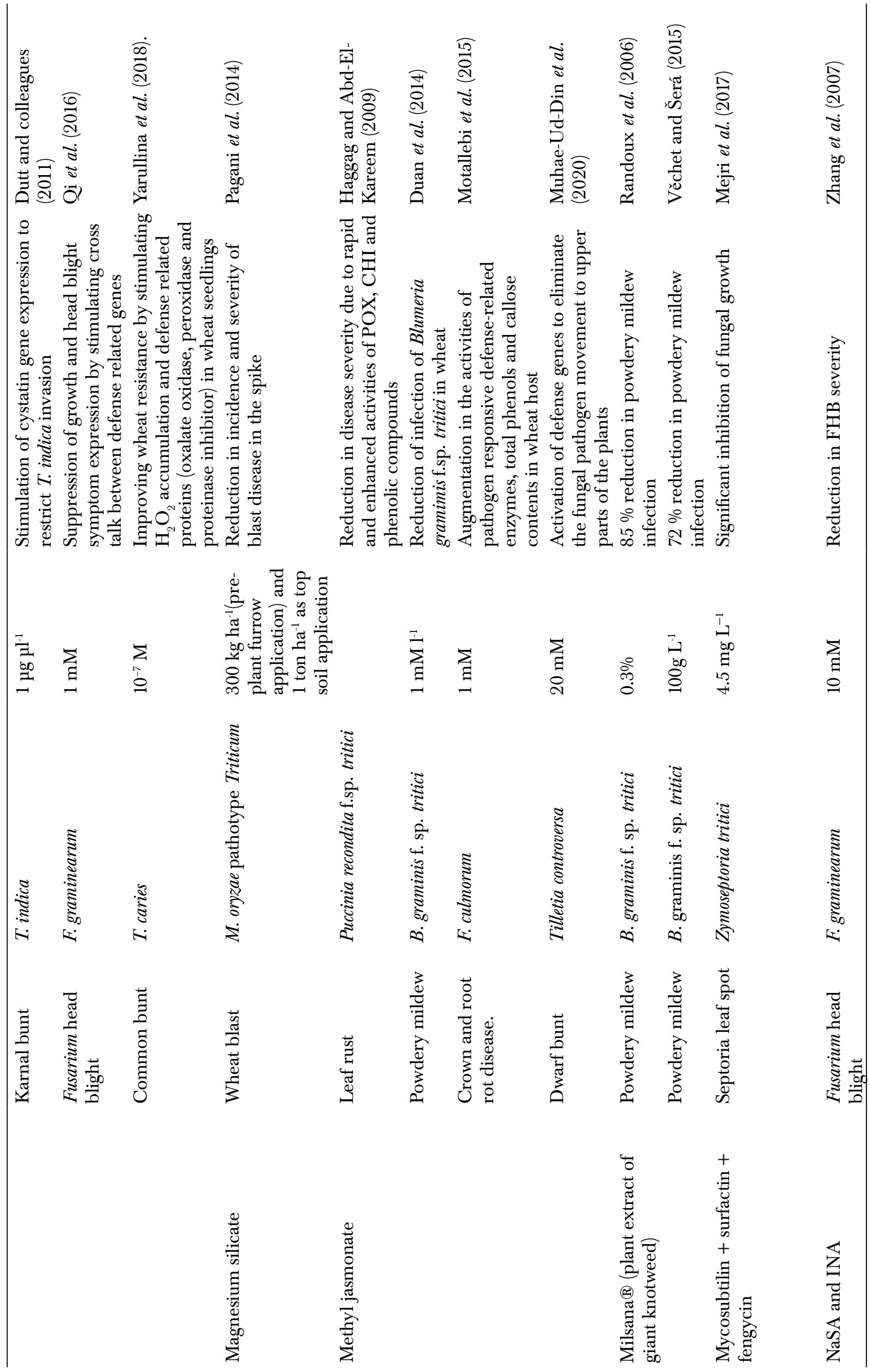




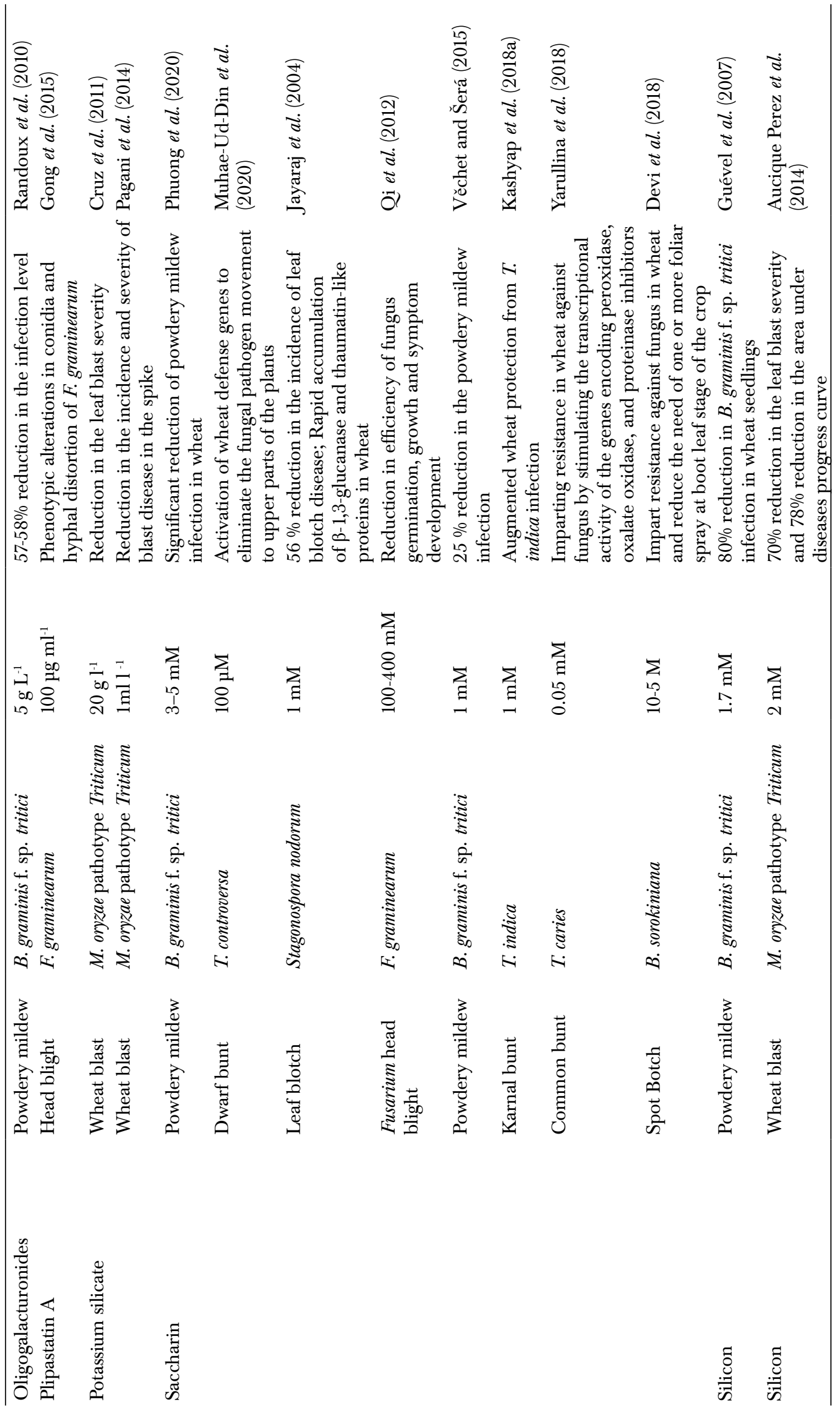


from $F$. graminearum infection (Reddy et al., 1999). It has been observed that chitosan can also stimulate induced resistance in winter wheat in response to the challenge inoculation of snow mould pathogen Microdochium nivale (Hofgaard et al., 2005). The similar group of researchers also documented that exogenous application of chitosan on wheat increased chitinase gene expression, but chitosan molecule also showed growth inhibition of $M$. nivale under in vitro experimentation (Hofgaard et al., 2005). Therefore, these research evidences clearly indicate the possibility of dual action of chitosan (i.e. induced resistance and direct antifungal action) in restricting the growth of $M$. nivale on wheat. Additionally, Hofgaard et al. (2005) also pointed out that these disease protection levels vary with disease pressure. Khan and Doohan (2009) evaluated the efficacy of chitosan for the management of $F$. graminearum and its associated mycotoxin contamination in wheat grains. They demonstrated that foliar spray of chitosan $(1 \mathrm{mg}$ $\mathrm{ml}^{-1}$ ) provided $81 \%$ and $76 \%$ reduction in expression of head scab disease symptoms in greenhouse and field experiments, respectively. Further, they also observed $\geq 74 \%$ reduction in the concentration of deoxynivalenol $(\mathrm{DON})$ toxin under both glasshouse and field conditions in response to foliar spray of chitosan. Later, research evidences regarding the efficacy of chitosan as a seed treatment to elicit resistance against $F$. graminearum in durum wheat has been published by Orzali et al. (2014). The results of both field and greenhouse trials revealed that seed treatment with chitosan $(0.5 \%)$ provided effective protection against the root and foot rot disease caused by $F$. graminearum. Kheiri et al. (2016) also provided supporting evidences regarding the inhibitory effect of chitosan against $F$. graminearum infection in wheat. They reported that foliar spray of both chitosan $(0.1 \%)$ and chitosan based nanoparticles $(0.5 \%)$ can be applied as antimicrobial agents owing to their biocompatibility, antimicrobial potential and a lower toxicity towards mammalian cells. Recently, Francesconi et al. (2020) tested the effect of foliar application of chitosan $(0.5 \%)$ at the flag leaf stage of wheat that resulted in the significant rise in plant growth and nitrogen balance index. However, it suppressed head scab disease caused by $F$. graminearum by down regulating the transcript of key genes associated with the cell growth, respiration, virulence, and trichothecene biosynthesis of the fungus. On parallel lines, Buzón-Durán et al. (2020) also demonstrated antifungal activity of chitosan oligomers 
(COS)-amino acid conjugate complexes $\left(1500 \mu \mathrm{g} \mathrm{ml}^{-1}\right)$ against $F$. culmorum. They noticed that COS-amino acid conjugate complexes reduced the head blight symptom development by $50-83.5 \%$ in Triticum spelta. These aforementioned research evidences clearly signify that the prior induction of resistance by non-toxic chitosan in plants has not only opened new frontiers for an ecofriendly disease management but also reduced the use of conventional health hazardous chemicals for plant disease.

\subsubsection{Salicylic acid (SA) and its derivatives}

Salicylic acid (SA) plays an essential role in regulating plant defense system and assisting plants to build resistance against biotrophic and hemibiotrophic pathogens (Grant and Lamb, 2006). SA and its functional analogs [e.g. $\beta$-amino-n-butyric acid (BABA), 2, 6-dichloroisonicotinic acid (INA), and benzothidiazoles (BTH)] are the most commonly investigated chemical group of molecules for inducing disease resistance in plants (Kashyap et al., 2018b; Kim et al., 2013; Conrath, 2006). Historically, the role of SA and its analogues (BTH) in augmentation of defense gene expression has been established by Görlach et al. (1996), while studying the effect of BTH $(0.3 \mathrm{mM})$ on wheat seedlings between 4-7 days prior to challenged inoculation with powdery mildew fungus, $B$. graminis $\mathrm{f}$. sp. tritici (Görlach et al., 1996). In this study, they also noticed that BTH is beneficial in inducing resistance in wheat against multiple pathogens such as Septoria spp. and Puccinia recondita causing leaf blight and brown rust disease, respectively. More interestingly, they observed that a single application of BTH $\left(30 \mathrm{~g} \mathrm{ha}^{-1}\right)$ is adequate to provide complete protection against powdery mildew fungus $(B$. graminis f. sp. tritici) in wheat throughout the season. Since then, this molecule has been tested and evaluated against a series of pathogens and host systems. As a consequence of encouraging results of resistance induction against a wide range of pathogens, this molecule has been released commercially in Europe and USA under the trade name Bion ${ }^{\circledR}$ and Actigard $\AA$, respectively (Eyles et al., 2010). It is important to mention here that the under field conditions, the performance of chemical elicitors varied in spatio-temporal manner and clearly evident in case of benzothiadiazoles (BTH), where plant host respond differently at different time points in response to chemical elicitor application (Bektas and Eulgem, 2015). On parallel lines, Heier et al. (2005) studied the effect of nitrogen fertilization, fungicides and resistance induction on Fusarium head blight (FHB) and related mycotoxin accumulation in wheat in response to BTH and Spirulina platensis application and reported equivalent effectiveness of PRI compounds and traditional fungicides. Further, they also noticed that excessive $\mathrm{N}$-fertilization has the ability to influence the efficacy of BTH and Spirulina platensis as mycotoxin levels rise in wheat grains, even under hostile conditions for Fusarium spp. The observations of environment influence on resistance induction in plants were supported by the study of Pasquer et al. (2005), where they reported a general high level expression of defense genes in plants grown under normal field conditions than glasshouse grown plants. Zhang et al. (2007) evaluated SA, 2, 6-dichloroisonicotinic acid (INA), $\beta$-aminobutyric acid (BABA) and sodium salt of salicylic acid (NaSA) for the management of FHB disease in wheat. The results revealed that foliar spray of NaSA and INA at $10 \mathrm{mM}$ on wheat heads at three days prior to pathogen challenge with Gibberella zeae significantly decline the severity level of disease. Further, they also noticed that $1 \mathrm{mM}$ concentration of NaSA, INA, and BABA is also equally effective in achieving same level of reduction in FHB disease severity, when applied on wheat head initiation stage at ten days prior to challenge inoculation with G. zeae. Interestingly, induction of FHB resistance in wheat is also possible with similar results, even at much lower concentration $(0.1 \mathrm{mM})$ of INA. Thabet (2008) experimentally showed that BTH and SA inhibit the leaf rust infection in wheat by stimulating the synthesis of pathogenesis related $(\mathrm{PR})$ protein and other peroxidase and phenolic compounds. Later, the effect of BTH $(1 \mathrm{mM})$ and SA (1000 $\left.\mu \mathrm{g} \mathrm{ml}^{-1}\right)$ on ISR was investigated by AlMaaroof $e t$ al. (2014) in wheat against yellow rust disease incited by Puccinia striiformis f. sp. tritici. They reported that BTH $(1 \mathrm{mM})$ and SA $\left(1000 \mu \mathrm{g} \mathrm{ml}^{-1}\right)$ are effective in reducing the infection level of $P$. striiformis f. sp. tritici. Further, they also demonstrated that the resistance to $P$. striiformis $\mathrm{f}$. sp. tritici has been induced by these chemical inductors in wheat genotypes due to the rapid synthesis of peroxidase, phenylalanine ammonia-lyase (PAL) and total phenolic compound in both moderately susceptible (cv. Tamuz-2) and susceptible (cv. AL-8/70) wheat genotypes. $\mathrm{BTH}, \mathrm{BABA}$ and SA at $1 \mathrm{mM}$ concentration were also tested to manage Karnal bunt (T. indica) under glass house conditions by Kashyap et al. (2018b). Results indicated 
that $1 \mathrm{mM}$ concentration of these compounds is adequate to suppress $T$. indica infection in wheat grown under greenhouse conditions. Moreover, elevated accumulation of PDF1.2, PR1 and PR5 with all tested compounds at three days post-inoculation was also noticed. Results suggest that these compounds primed wheat seedlings to show prompt, rapid and strong response to $T$. indica infection by triggering SA and JA/ ET mediated defense pathway. Yarullina et al. (2018) also observed stimulatory effect of $\mathrm{SA}(0.05 \mathrm{mM})$ in imparting resistance against $T$. caries by stimulating the accumulation of $\mathrm{H}_{2} \mathrm{O}_{2}$ and transcriptional activity of the genes encoding peroxidase, oxalate oxidase and proteinase inhibitors. Devi et al. (2019) reported that seed soaking with $\mathrm{SA}\left(10^{-5} \mathrm{M}\right)$ induced resistance against B. sorokiniana fungus in wheat. Further, they also mentioned that for prolonged effect of tested inducers on disease resistance requires one or more foliar sprays at boot leaf stage of the crop. Muhae-Ud-Din et al. (2020) showed that exogenous application of SA $(20 \mathrm{mM})$ was able to reduce the infection of $T$. controversa in wheat roots, coleoptiles and anther tissues of a highly susceptible wheat cultivar (cv. Dongxuan 3). Bellameche et al. (2020) explored the prospect of chemical inducer application in the management of Zymoseptoria tritici infection on wheat. Their study concluded that BABA $(15 \mathrm{mM})$ applied as a soil-drench effectively safeguards the wheat seedlings from $Z$. tritici infection. However, soil-drenching of wheat seedlings with BTH $(2 \mathrm{mM})$ results in delayed $Z$. tritici growth during the early seed germination stage.

Heptanoyl salicylic acid (HSA) obtained by esterification of $2-\mathrm{OH}$ benzoic acid with heptanoic acid have been reported to provide protection in wheat against powdery mildew fungus. Muchembled and colleagues (2006) demonstrated that single foliar spray of $1 \mathrm{gl}^{-1}$ solution of HSA is able to provide $70 \%$ protection against B. graminis f. sp. tritici infection in wheat plants.

\subsubsection{Jasmonic acid}

Jasmonic acid (JA) plays an imperative part in enhancing plant resistance to diverse types of plant pathogens. The efficacy of JA in stimulating defense resistance against Stagonospora nodorum fungus in wheat has been studied by Jayaraj et al. (2004). The results of the study indicated that one day prior to challenge inoculation of Stagonospora nodorum, JA $(100 \mu \mathrm{M})$ provided $56 \%$ reduction in the incidence of leaf blotch disease in wheat seedlings under greenhouse conditions. Similarly, Dutt and colleagues (2011) treated resistant (HD-29) and susceptible (WH542) wheat varieties with JA $\left(1 \mu \mathrm{g} \mathrm{\mu l}^{-1}\right)$ followed by artificially challenged inoculation of $T$. indica sporidial suspension to study its influence on Karnal bunt disease development. They observed that exogenous application of JA helps in improving wheat defense system against KB by stimulating cystatin gene expression. Similar report of defense activation in susceptible wheat varieties (cv. Chinese Spring and Pumai 9) by exogenous application of methyl jasmonate (MeJA; $1 \mathrm{mM} \mathrm{l}^{-1}$ ) against powdery mildew exposure has been published (Duan et al., 2014). Further, it has been noticed that after exogenous application of MeJA, it passes into plant tissue via stoma and trigger esterase driven hydrolysis in the cytoplasm to produce endogenous JA, which is responsible for longdistance signal communication between plants to activate defense system against $B$. gramimisf.sp. tritici and reached maximum within 2- $5 \mathrm{~h}$ post-inoculation. Besides this, it has been observed that JA also induce elevated expression level of PR1, PR2, PR3, PR4, PR5, PR9, PR10 and Ta-JA2 genes in wheat plants. Motallebi and team (2015) also explored the effect of MeJA $(1 \mathrm{mM})$ in wheat genotypes after artificial exposure of $F$. culmorum fungus responsible for crown and root rot disease. They observed augmented activities of pathogen responsive defense-related enzymes (PAL, SOD, POX, CAT, LOX and PPO), total phenols and callose (glucose residues linked together through $\beta$-1,3linkages) contents in wheat host. Exogenous application of JA $(1 \mathrm{mM})$ is also reported to suppress $F$. graminearum growth and head blight symptom expression in wheat by triggering cross talk between a series of defense related genes (ATB2, ExpB6, LEA Td16, PR1, Pdf1.2 and PR4) (Qi et al., 2016). Protection potential of JA in wheat plants infected with $T$. caries has been demonstrated by Yarullina et al. (2018). Further, they highlighted that soaking of wheat seeds for three hours in JA $\left(10^{-7} \mathrm{M}\right)$ helps in improving resistance against pathogen by stimulating accumulation of defense related proteins (oxalate oxidase, peroxidase and proteinase inhibitor) in plant tissues. Recently, MuhaeUd-Din et al. (2020) revealed that the invasion capability of $T$. controversa decreased in temporal manner after root and seedling treatment with $\mathrm{MeJA}(100 \mu \mathrm{M})$ by activating COI1-1 and COI1-2 genes mediated defense signaling system. The above mentioned research evidences clearly supported the hypothesis that JA and its analogues protect 
wheat seedlings by activating defense signaling systems in spatio-temporal manner.

\subsubsection{Lipopolysaccharides}

Lipopolysaccharides (LPS) and lipooligosaccharides are generally found in the exterior surface of Gram negative bacteria and are reported to impart disease resistance against diverse types of plant pathogens (Ranf, 2016; Erbs and Newman, 2003). For instance, Ortmann and Moerschbacher (2006) reported the spent growth medium and Pantoea agglomerans derived exopolysaccharides (EPS) served as important priming molecules to impart stress resistance in suspension-cultured wheat cells. Similar protection evidences in wheat against $P$. recondita $\mathrm{f}$. sp. tritici has been achieved, when culture filtrate of $P$. agglomerans were sprayed on wheat leaves (Kempf and Wolf 1989). Similarly, lipopeptides (surfactin, mycosutilin and fengycin) produced by Bacillus subtilis have been reported to induce resistance and protect wheat from $B$. graminis f.sp. tritici infection (Khong et al., 2012). Under field conditions, surfactin and mycosubtilin provided $41 \%$ and $44 \%$ protection, respectively, when sprayed on wheat leaves at rate of $4 \mathrm{~g} \mathrm{ha}^{-1}$. Here, it is important to mention that no direct antifungal effect of LPS was recorded against conidial germination of B. graminisf. sp. tritici, irrespective of the tested concentrations (Khong et al., 2013). Further, they also performed gene expression analysis to investigate elicitor and priming effects of surfactin and mycosubtilin on the activation of defense-related genes (POX2, POX381, $L O X$, AOS and PR7) in response to pathogen inoculation. Interestingly, only surfactin displayed stimulation in the expression of defense-related genes in response to $B$. graminis f.sp. tritici exposure, while mycosubtilin did not exhibit any priming effect (Khong et al., 2013). These research evidences clearly illustrate that the role of LPS in disease resistance induction through elicitation or augmentation depends on the targeted pathogen and LPS type. In addition to rhizospheric plant growth promoting rhizobacteria (PGPRs), cyclic lipo-polysacharides (CLP) production from phyllospheric microbes have also been reported for resistance induction. For instance, Bacillus liquefaciens isolated from wheat spikes infected with Fusarium graminearum has been reported to synthesize CLPs (iturin, plipastatin and surfactin) with strong inhibitory activities against $F$. graminearum (Gong et al., 2015). The optical and fluorescence microscopy analysis clearly showed the significant phenotypic alterations in conidia and hyphal distortion of $F$. graminearumin response to iturin A $(50 \mu \mathrm{g} / \mathrm{ml})$ or plipastatin A (100 $\mu \mathrm{g} / \mathrm{ml}$ ) treatment. Mejri et al. (2017) also explored the antagonistic nature of CLPs (mycosubtilin, surfactin and fengycin) derived from Bacillus subtilis at a concentration of $100 \mathrm{mg} \mathrm{L}^{-1}$ on wheat (cv. Dinosor and Alixan) against Zymoseptoria tritici and recorded significant reduction of disease severity, when applied two days prior to fungal inoculation. Further, they also got success in achieving $82 \%$ disease reduction by applying mycosubtilin+surfactin containing formulations on Dinosor genotype. Further, in vitro and in planta research evidences also support the conclusion of significant inhibition of fungal growth by mycosubtilin based formulations. However, it is worth to mention here that $1.4 \mathrm{mg} \mathrm{L}^{-1}$ concentration of both mycosubtilin and mycosubtilin + surfactin and $4.5 \mathrm{mg} \mathrm{L}^{-1}$ of mycosubtilin + surfactin + fengycin showed maximal inhibitory activity and thus indicating that efficacy of these products depends largely on antagonistic activity. In contrast, surfactin and fengycin did not show any direct antifungal action against the fungus and therefore signifying their role as resistance inducers rather than biofungicides against $Z$. tritici in wheat. On parallel lines, Mire and colleagues (2018) also demonstrated that surfactin extract of B. amyloliquefaciens S499 impart protection against $Z$. tritici in wheat by triggering both SA- and JA mediated defense system. It has been observed that surfactin is able to provide $70 \%$ protection in wheat against $Z$. tritici and equivalent in antagonistic nature of commercialized elicitor product, Bion ${ }^{\circledR 50 W G ~(M i r e ~} e t$ al., 2018). In summary, the aforementioned studies clearly indicate the potential of LPS to protect wheat seedlings against fungal infection and their involvement in the activation of defense signaling pathway.

\subsubsection{Proteins and peptides}

A plenty of studies have revealed that proteins and peptides play an important role in disease-resistance against fungal pathogens in plants. For instance, cell wall proteins derived from Pythium oligandrum is reported to decline the infection and symptoms caused by $F$. graminearum on wheat spikelets (Takenaka et al., 2003). This concept has been developed and commercialized by Novartis (now Syngenta) as Bion ${ }^{\circledR}$ (Kessmann et al., 1996). Research evidences highlighted that this compound is highly 
effective and provides protection up to 10 weeks against powdery mildew infection in wheat (Görlach et al., 1996). Besides this, Reignault and team (2004) also evaluated the efficacy of other proteins and peptides compound such as Iodus $40 \AA$, Milsana $\AA$, salicylyl heptanoate, trehalose, and pectic oligosaccharides against powdery mildew disease of wheat and attained significant reduction in the level of infection after application of these compounds. Another peptide 'syringolin' isolated from $P$. syringae pv. syringae bacterium (Wäspi et al., 1998) was also studied for inducing resistance in wheat against fungal infection. It has been observed that Syringolin A induces resistance in wheat towards powdery mildew fungus by accumulating defense gene transcripts when applied before inoculation (Wäspi et al., 2001). Naguib et al. (2018) investigated the efficacy of wheat seed priming with defensin-like protein to protect wheat against $F$. oxysporum infection. They observed that priming with defensin protein helps the wheat seedlings to overcome the Fusarium infection by improving the antioxidant system as well as hydrolysis processes. Further, they also confirmed that defensin priming enhanced the phosphatase and amylase activities and helped in the solubilization of phosphate and sugar, which in turn served in the augmentation of the metabolic activity of the defensin-primed plants.

\subsubsection{Trehalose}

Trehalose (TH; $\alpha$-D-glucopyranosyl-[1-1]- $\alpha$-Dglucopyranoside) is a natural non-reducing disaccharide. It has been reported to present in diverse types of living organisms including fungi. Several researches revealed that trehalose is able to impart resistance against biotic and abiotic stresses in plants (Yogita et al. 2015; Luo et al., 2021; Sadak et al., 2019; Drennan et al., 1993). For instance, significant decline in infection intensity of $B$. graminisf. sp. triticifungus have been observed in response of exogenous application of trehalose (Reignault et al., 2001). It has been reported that wheat plants sprayed with a trehalose solution $\left(15 \mathrm{~g} \mathrm{~L}^{-1}\right), 48$ hours prior to inoculation with $B$. graminis f. sp. tritici provided 50-95\% protection from fungal infection. However, the level of protection depends on the number and frequency of trehalose solution spray (Reignault et al., 2001). Later, Tayeh et al. (2014) also explored the priming effect of trehalose in wheat against powdery mildew infection and noticed that exogenous application of trehalose enhanced the expression level of multiple types of defense related genes (e.g. chi, chi1, chi4 precursor, PR1 and oxalate oxidase). Further, they also noticed that trehalose spraying may alter the lipid metabolism and boost wheat defense system by enhancing lipoxygenase and lipid-transfer protein (LTP) gene expression in wheat (Tayeh et al., 2014). These limited and preliminary investigations clearly indicate the potential of exogenous application of trehalose to protect wheat plants from fungal infection.

\subsubsection{Silicon}

There are many recent reports which highlighted the role of silicon $(\mathrm{Si})$ in reducing disease severity levels in plants by different means which includes: i) averting pathogen ingression via structural reinforcement; ii) hampering pathogen colonization through activation of SAR; iii) inhibiting pathogen by triggering production of antimicrobial compounds; and iv) activation of multiple signaling cascades associated with the augmentation of defense-related gene expression (Islam et al., 2020; Wang et al., 2017; Remus-Borel et al., 2005). The prime advantage provided by $\mathrm{Si}$ in reference to plant resistance against fungal infections is the accumulation of $\mathrm{Si}$ in epidermal tissue followed by activation of a series of processes such as formation of complexes with organic compounds in cell walls, generation of phenolic compounds and other compounds such as phytolexin, glucanase and peroxidase for regulating pathogenicity as well as other stress-related gene expression, which ultimately lead to prevent pathogen invasion and colonization in plant cell (Sakr, 2016; Belanger et al., 2003). Bélanger and associates (2003) noticed that that exogenous application of $\mathrm{Si}$ amendments in the form of nutrient solution or calcium silicate slag provided protection against B. graminis f.sp. tritici infection in wheat. Further, it has been demonstrated that epidermal cells of plants supplied with Si helps to restrict the fungus growth by arresting papilla formations. Moreover, it has been observed that phenolic material not only stacked along the cell wall, but also associated with altered integrity of haustorian and collapsing of conidial chains of B. graminisf.sp. tritici in Si primed plants. Si (100 $\mathrm{mg} \mathrm{L}{ }^{-1}$ ) amendment in soil reported to enhance wheat tolerance against diseases incited by $B$. graminisf.sp. tritici, Phaeosphaerian odorum and $P$. recondita (Rodgers-Gray and Shaw, 2004). Rémus-Borel and colleagues (2005) highlighted that wheat plants treated with Si produce 
antifungal aglycones metabolites in response to $B$. graminis f.sp. tritici infection than plants deprived of Si treatment. Later, Guével et al. (2007) documented that wheat roots treated with $\mathrm{Si}(1.7 \mathrm{mM})$ resulted in the reduction of $B$. graminis f.sp. tritici infection by $80 \%$. Chain et al. (2009) revealed that $B$. graminis $\mathrm{f}$. sp. tritici infection can alter about 900 genes in wheat seedlings. However, in case of Si-primed wheat seedling, they noticed very minor alterations in gene expression when exposed to fungal infection, concluding that $\mathrm{Si}$ is helpful in preventing the stress triggered by $B$. graminisf. sp. tritici infection in plant (Chain et al., 2009). Further, disease protection evidences of Si-amendments in soil against wheat blast disease have been provided by Filha et al. (2011). They demonstrated that the area under blast progress curve and the number of lesions significantly reduced in response to Si treatment in wheat, however, incubation period of Pyricularia grisea was significantly enhanced by $28.2 \%$ in case of Si-treatment. They also confirmed that augmentation of chitinase and peroxidase activity defined the potential of Si to reduce wheat susceptibility to blast disease. Sousa et al. (2013) revealed that exogenous application of $\mathrm{Si}$ restricts the hyphal penetration of $P$. oryzae upto the first-invaded epidermal cell of infected wheat leaves. On parallel lines, Domiciano et al. (2013) also reported that exogenous application of Si delays the penetration of $B$. sorokiniana infection in the epidermal cells and thereby reduces fungal colonization in foliar tissue of wheat. Pagani and team (2014) also studied the efficacy of foliar application of $\mathrm{SiO}_{2}\left(30 \mathrm{~g} \mathrm{l}^{-1}\right)$ along with furrow application of calcium and magnesium silicate $\left(300 \mathrm{~kg} \mathrm{ha}^{-1}\right)$ for wheat blast disease management under field conditions. They observed that wheat plants treated as foliar or furrow application of silicate showed significantly low disease incidence, although effect was genotype dependent as BRS-264 genotype is more responsive to $\mathrm{Si}$ applications compared to BR-18 genotype. Later, Silva et al. (2015) conducted histochemical study and confirmed the involvement of Si in the potentiation of flavonoids biosynthetic pathway in wheat leaves suffered from $P$. oryzae infection. Overall, it seems that $\mathrm{Si}$ is involved in imparting resistance against wheat diseases by modulating interactive defense gene based signaling and enzymatic production.

\subsubsection{Phosphites}

A plenty of published literature described phosphites as a metal salts of phosphorous acid and possess unique characters of low toxicity, high solubility, systemic (both upward and downward) translocation (Carmona et al. 2018; Deliopoulos et al., 2010; Reuveni, 1997). Besides this, they have been reported to elicit systemic acquired resistance. For instance, potassium phosphite $\left(\mathrm{K}_{2} \mathrm{HPO}_{3}\right)$ has been reported to control numerous plant pathogens (Kashyap and Dhiman, 2009; Lovatt and Mikkelsen, 2006; Forster et al., 1998). In wheat, Cruz and team (2011) reported the role of phosphite $\left(1500 \mathrm{ml} \mathrm{ha}^{-1}\right)$ in reducing the severity of wheat blast disease under controlled conditions. Similar positive effect of phosphite $\left(1 \mathrm{ml} \mathrm{l}^{-1}\right)$ in protecting wheat from Magnaporthe grisea infection under two years' field experimentation has been reported by Pagani et al. (2014). Besides this, Santos et al. (2011) has also obtained positive effects of phosphite treatment in reducing the infection of Drechslera tritici-repentis and $B$. sorokiniana in wheat plants, although, the effect varied with the type of wheat species and pathosystem.

\subsubsection{Glycerol}

Several studies recognized glycerol as an on-toxic, environmental friendly, edible and biodegradable sugar alcohol. Li et al. (2016) provided evidences that foliar spray application of glycerol (3\%) stimulates wheat defense without showing any significant injury to wheat leaves when challenged inoculations were made with B. graminisf. sp. tritici at least 1-2 days' post glycerol treatment. Further, they also observed that exogenous treatment of glycerol stimulates the expression level of glycerol-3-phosphate (G3P), pathogenesis-related genes (TaPR-1, TaPR-2, TaPR3, $T a P R-4$, and $T a P R-5)$ and produces reactive oxygen species before fungal infection along with $\mathrm{SA}$ accumulation in the wheat leaves. Under field conditions, it was noticed that glycerol sprays significantly lessen powdery mildew disease severity without hampering wheat seed quality. Recent whole transcriptome analysis of wheat plants infected by B. graminis f. sp. tritici after glycerol exposure highlighted that glycerol $(3 \%)$ treatment regulates fatty acid metabolism (e.g. TaGLI1, TaACT1, and TaSSI2) and hormones cross-talk and also supports the earlier reports of enhanced expression of $P R$ genes $(P R-1, P R-3, P R$ 10, callose synthase, PRMS, RPM1, peroxidase, HSP70 and HSP90) which together can strengthen wheat 
resistance potentialities against $B$. graminis f. sp. tritici $(\mathrm{Li}$ et al., 2020). Further, it has been noticed that glycerol induced JA and SA levels, while reduced the auxin (IAA) levels in wheat in response to fungal infection lead to the accumulation of glycerol-3-phosphate (G3P) and oleic acid (OA18:1) metabolites at the zone of infection. More importantly, it is worth mentioning here that glycerol used as a cosolvent medium for agrochemicals and therefore seems to have potent application in wheat field as an ecocompatible agrochemical to protect crop from pathogens of different nature.

\subsection{Biological inducers}

There are lot of published documents that highlight the positive effects of microbes on disease supersession by eliciting ISR (Kashyap et al., 2018b; Srivastava et al., 2012). The first evidence in context to the microbe mediated induction of induced resistance (IR) to protect wheat from diseases came from pioneering research of Kilic-Ekici and Yuen (2003). These researchers experimentally illustrated that both live and heat killed cells of Lysobacter enzymogenes strain $\mathrm{C} 3$ have the ability to induce resistance against $B$. sorokiniana and reduced Bipolaris leaf spot development on tall fescue and wheat. Additionally, they also reported that the L. enzymogenes application induces non-specific and durable resistance with elevated activities of peroxidase enzymes in response to the challenged inoculation of B. sorokiniana inoculation on wheat (Kilic-Ekici and Yuen, 2003). Al-Ani and colleagues (2011) reported that Pseudomonas fluorescence, Azospirillum irakense, sea force extract and elsa fungicide $\left(1 \mathrm{ml} \mathrm{l}^{-1}\right)$ have the potential to stimulate ISR and enhance wheat and barley growth when exposed to barley yellow dwarf virus infection. Further, they also observed that $P$. fluorescence is more efficient in controlling barley yellow dwarf virus in comparison to $A$. irakense, Sea force extract and Elsa. They also noticed that the effect of treatment is more pronounced in partially resistant genotypes (cv. IBA 99, Arivate and Karonea) than the susceptible ones (Hashmia and Kara).

The research evidences on the involvement of rhizosphere microbe in the induction of phenylpropanoid cascade and subsequent stimulations of ISR against $B$. sorokiniana in wheat has been provided by Singh et al. (2016). They revealed the up-regulation of phenylpropanoid cascade and manifold rise in the activities of PAL, peroxidase and chitinase are responsible for the induction of ISR in plants co-inoculated with B. amyloliquefaciens B-16 and T. harzianum UBSTH-501 strains. Similar observations were also noticed by Singh and Jha (2017), where plant growth promoting bacterium, Stenotrophomonas maltophilia SBP-9 was reported to induce ISR to protect wheat plants against $F$. graminearum by rising the activities of defense enzymes (e.g. PAL, $\beta-1,3$ glucanase, PO and PPO). Samain et al. (2017) identified the potential of paenimyxin lipo-polypeptide elicitor of Paenibacillus sp. strain B2 in stimulating ISR against Septoria tritici. Further, they also mentioned that Paenibacillus strain B2 is able to provide more than 59\% protection against Septoria triticiblotch by ISR triggered as a consequence of rise in expression level of pr1, lox, Aos, peroxidase, oxo and gst genes. Moreover, they also highlighted role of paenimyxin elicitor in providing $76 \%$ local protection against Septoria tritici with strong activation of defense related genes (e.g.glu, lox, aos, pal, chs, oxo, and gst). Here it is important to mention that Paenibacillus sp. PB2 strain is also reported to stimulate wheat root colonization by Curtobacterium plantarum strain EDS (Samain et al., 2017) and therefore results in wheat growth promotion.

A large body of published literature outlines the biocontrol potentialities of Bacillus species, owing to their inherent abilities to be heat tolerant, produce desiccation-resistant endospores and survive under high temperature, nutrient deprived niches and unfavorable $\mathrm{pH}$ with better fitness and stability (Kushwaha et al. 2020; Solanki et al., 2015; Singh et al. 2014; Solanki et al. 2012). Burkhanova et al. (2017) documented that B. subtilis and Bacillus thuringiensis also have the ability to stimulate ISR in wheat plants against Septoria nodorum infection. They observed that Bacillus strains have the capacity to survival endophytically with strong antagonistic interaction towards $S$. nodorum infection. Interestingly, they also reported that B. subtilis $26 \mathrm{D}$ reduce leaf blotch symptom by suppressing the catalase activity and augmenting the enzymatic activities of peroxidase and $\mathrm{H}_{2} \mathrm{O}_{2}$ content along with strong expression of pathogenesis related defense genes (e.g. $P R-1, P R-6$, and $P R-9)$, which signifies the involvement of SA-dependent pathway, however, B. thuringiensis V-5689 and V-6066 are also observed to stimulate JA/ET-dependent pathway (Burkhanova et al., 2017).

The genus Trichoderma has received significant prominence in past several decades because of their strong antagonistic 
abilities against a wide spectrum of fungal pathogens and plant growth promotion triggered by ISR (Kashyap et al. 2020c; Kashyap et al., 2017; Rai et al., 2016a; Rai et al., 2016b; Srivastava et al., 2012; Solanki et al., 2011). Cordo et al. (2007) reported that Trichoderma spp. can protect wheat plants from $S$. tritici infection by triggering host defense. Seed coating with T. harzianum Th5 is reported to be the most efficacious application technique for restricting the spread of leaf blotch disease in wheat. It has been observed that seed coating of T. harzianum has the ability to reduce the antifungal proteolytic activity in wheat apoplast when exposed to S. tritici infection. Moreover, it has been noticed that endogenous germinlike protease inhibitor coordinated the proteolytic action and stimulated ISR against $S$. tritici. On parallel lines, Stocco et al. (2015) also reported the induction of ISR by $T$. harzianumin wheat when exposed to $Z$. tritici. The reduction of the Septoria leaf blotch severity due to ISR activation has been strongly supported by the fact of strong expression of defense-related proteins at sites distant from the location of the Trichoderma strain when challenged inoculated with fungal pathogens. Biological control of $P$. graminis f. sp. tritici causing stem rust in wheat has been reported by the exogenous application of Trichoderma spp. and arbuscular mycorrhizal (AM) fungi based formulations (El-Sharkawy et al., 2018). Under natural field conditions, it has been observed that AM fungi and Trichoderma spp. can improve the wheat growth and yield parameters and reduce disease pressure by rapid synthesis of peroxidase, polyphenol oxidase and total phenol content (El-Sharkawy et al., 2018). It is worth to indicate here that the synergistic action of Trichoderma spp. and AM fungi helps in inducing the SA, JA and ET regulated defense mechanisms and thus clearly explains the superiority of the combined treatment (arbuscular mycorrhizal $+T$. harzianum $\mathrm{HL} 1+T$. viride HL5) over individual (El-Sharkawy et al., 2018). Draz et al. (2019) mentioned that prior applications of $10,000 \mathrm{mg} \mathrm{L}^{-1}$ of plant extracts (e.g. Acalypha wilkesiana, Lantana camara, Lazesonia inermis, Melia azedarach and Punica granatum) under field conditions can induce resistance in wheat against $P$. triticina by triggering the synthesis of defenserelated enzymes. In nut shell, it seems that biological inducers are one of best option and moreover they are thought to open the way towards the development of bio-control tools against wheat diseases and sustainable cultivation of wheat.

\section{Induced resistance as a component of integrated disease management (IDM)}

Biological control and resistance augmentation by microbes and chemicals have a prospective future to serve as an essential element in any integrated disease management module. Research evidences indicate that ASM has been explored extensively in combination with myriad of fungicides for the management of plant diseases. More specific evidence has come from the experimentation, where a tank mixture of ASM and Azoxystrobin has been reported to provide excellent control of powdery mildew and leaf blotch (Septoria tritici) disease in wheat (Stadnik and Buchenauer, 1999). Further, it has been observed that foliar applications of urea with BTH not only enhance wheat yields but also provides effective control of powdery mildew disease in wheat, regardless of the observation of increase in powdery mildew symptoms when urea (as a nitrogen source) applied alone (Stadnik and Buchenauer, 1999). Similarly, ASM has been reported to enhance the efficacy of Cypronidil against powdery mildew. In Denmark, Jorgensen et al. (1997) conducted several field trials of ASM efficacy as an integrated control strategy for cereal disease management and got excellent results against fungal infection in wheat (Jorgensen et al., 1997). In Brazil, Santos and team (2011) demonstrated that combined application of phosphite with pyraclostrobin + epoxiconazole $(400 \mathrm{ml}$ $\left.\mathrm{ha}^{-1}\right)$, pyraclostrobin + epoxiconazole $\left(300 \mathrm{ml} \mathrm{ha}^{-1}\right)$ and pyraclostrobin + epoxiconazole $\left(400 \mathrm{ml} \mathrm{ha}^{-1}\right)$ is effective in the management of leaf rust, powdery mildew and brown spot diseases of wheat.

\section{Factors affecting induced resistance}

A large body of evidences indicated that the expression of IR in wheat is greatly influence by the type of wheat genotype. For instance, Pagani et al. (2014) documented the influence of wheat genotypes on the expression of IR in wheat against wheat blast fungus, $M$. oryzae pathotype Triticum. They described that BRS 264 genotype is more predisposed to stimulate beneficial effect in response to Si treatment than BR 18 genotype. Similarly, Santos $e t$ al. (2011) also noticed positive response of phosphite treatment to manage Drechslera tritici-repentis and $B$. sorokiniana infection in wheat depending on the crop species and on the pathosystem. It is worth to mention here that the findings of both the studies came from the 
experiments employing single pathogen isolate or single host genotype which might lead to the wrong conclusions that may alter the efficacy of elicitors in practice. Newton et al. (2004) revealed that bacterial inocula applied in previous crop has the ability to influence fungal disease development in succeeding non-host crops and therefore indicates penalties for commonly practiced agronomic interventions including rotations. They also explained these results by corroborating the results with synergistic enzyme theory and explained the severe effects on hemibiotrophic pathogens and powdery mildew disease in wheat is due to heavy load of bacterial inoculum. Further, they also explained that the disease outcome may not be directly attributed to the interaction between the bacteria and B. graminis inoculum, but there is also a possibility of induced susceptibility or even nutritional effect as heavy dosages of nitrogen is responsible for enhancing susceptibility of cereals towards mildew infection. Statistically, Newton et al. (2000) also determined that high nitrogen level enhance powdery mildew severity by 4.58 times in comparison to low level of nitrogen under high inoculum load. Besides this, expression of resistance is also reported to be influenced by various other organisms dwelling in the environment in direct or indirect fashion. Several workers explained that both humidity and light have strong effect on the expression of defense-related genes, including ROS production (Mateo et al., 2004; Zhou et al., 2004). Fobert and Després (2005) clearly mentioned that amount and duration of light directly affects the chloroplast and redox status of cells and thereby is directly involved in the alteration of SAR stimulation (Fobert and Després, 2005). This is true in case of wheat, where expression of yellow rust resistance gene is dependent on light intensity (Ash and Rees, 1994). All above mentioned studies highlighted that the expression of IR is not stable and is greatly influenced by host, plant age, tissue maturity and edaphic factors etc. Therefore, it is essential to take these factors into account when induced resistance is practiced under field conditions for the management of wheat diseases.

\section{Consequences of resistance induction}

Induction of resistance is reported as a costly relationship in terms of yield forfeit and more over it triggers under optimal conditions only after the pathogen recognition (Walters et al., 2013). It has been well documented that resistance $(\mathrm{R})$ genes and matching virulence have been taking the energy from host in terms of fitness to the pathogen and its selection stabilization (Vanderplank, 1968). This has been experimentally confirmed by Tian $e t$ al. (2003) in A. thaliana. Heil et al. (2000) investigated the effects of ASM triggered IR on yield penalties in absence of pathogen pressure. They described that ASM treatment in wheat reduced biomass, ear and grain numbers and moreover got noticeable effects under nitrogen limited conditions. These results clearly reveal the allocation cost effect of ASM and supports the 'growth-differentiation balance' hypothesis of Herms and Mattson (1992), which indicates that a metabolic competition between processes engaged in the plant growth are obligatory for plant differentiation, such as synthesis of chemical and metabolites for plant defense. These findings clearly encourage the need of research on ecologically realistic manner in the agricultural systems to attain a reliable risk assessment of ISR in wheat protection for its successful application in agriculture.

\section{Future challenges and directions}

Recent research progress in the dissection of molecular basis for priming, plant immunity, SAR and ISR indicate a wider role for plant defense activating compounds. Several compounds of biological and non-biological origin are gaining significant momentum in curtailing the use of health hazardous chemicals for wheat disease management. Still, there are several researchable issues that need attention for effective amalgamation of resistance inducers into wheat protection package and for their wider use in farmer's fields, which are enlisted as follows:

- Compounds inducing resistance have played important functions in wheat-pathogen interactions. Therefore, research investigation on the structure and function of these compounds in plants, as well as the underlying genetic cascade of wheat-associated pathogens will be advantageous to develop effective disease management tools and to upsurge disease resistance in wheat plants.

- There is a need to discover more effective resistance inducers against wheat disease and the information attained in the last few years on SAR, ISR and RNA silencing mechanisms and the interactions between them, may guide researchers to develop new molecules effective against wheat pathogens. 
Additionally, deep research efforts are sought to comprehend the effects of nutrition, timing and dosages of application and genotypic effects after application of resistance inducers.

- A deep insight into the genetic alterations as a consequence of defense priming and pathogen resistance will offer valuable information for developing disease-resistant varieties by exposing parental plants to resistance inducers, as well as for the synthesis of novel plant protection chemicals that can trigger plant's intrinsic disease resistance machinery.

- A number of reports have emphasized that ISR stimulating plant growth promoting microbes (PGPM) as beneficial tool to control wheat diseases that are sensitive to JA- and ET-dependent defenses. Thus, incorporating ISR stimulating PGPM into disease management framework in juxtaposition with other stratagems will be worth to explore in the present arena of climate change.

\section{Funding}

Funding received from Indian Council of Agricultural Research (ICAR) under the institute project entitled "Biotic stress management in wheat by integrating innovative approaches (CRSCIIWBRCL202000500198)”.

\section{Author Contributions}

All the authors contributed to the article and approved the submitted version.

\section{Conflict of Interest}

No commercial or financial relationships that could be construed as a potential conflict of interest.

\section{Compliance with ethical standards}

Yes

\section{References}

1. Abdul Malik NA, IS Kumar and K Nadarajah. 2020. Elicitor and receptor molecules: Orchestrators of plant defense and immunity. International Journal of Molecular Sciences 21(3):963. https://doi.org/10.3390/ ijms21030963.

2. Ahmad S, R Gordon-Weeks, JA Pickett and J Ton. 2010. Natural variation in priming of basal resistance: from evolutionary origin to agricultural exploitation. Molecular Plant Pathology 11: 817-827.
3. Al-Ani RA, MA Adhab, MA El-Muadhidi and MA Al-Fahad. 2011. Induced systemic resistance and promotion of Wheat and barley plants growth by biotic and non-biotic agents against Barley yellow dwarf virus. African Journal of Biotechnology 10(56): 12079-12084.

4. Alexandersson, E, T Mulugeta, A Lankinen, E Liljeroth and E Andreasson. 2016. Plant resistance inducers against pathogens in solanaceae speciesfrom molecular mechanisms to field application. International Journal of Molecular Sciences 17:1673.

5. Al-Maaroof E, AH Fayadh and FA Fattah. 2014. Use of some chemical inducers to improve wheat resistance to Puccinia striiformisf. sp. tritici. Ratarstvo i Povrtarstvo 51: 83-90.

6. Al-Maaroof EM, M Hovemoler, R Ali, H Maahood, A Naser, and L Muhammed. 2015. Detection of Yr27 virulence in Puccinia striiformisf. sp. tritici populations on wheat in Iraq. Journal of Wheat Research 7 (1):39-47.

7. Ameye M, K Audenaert, N De Zutter, K Steppe, L Van Meulebroek, L Vanhaecke, D De Vleesschauwer, G Haesaert and G Smagghe. 2015. Priming of wheat with the green leaf volatile Z-3-hexenyl acetate enhances defense against Fusarium graminearum but boosts deoxynivalenol production. Plant Physiology 167:1671-1684.

8. Anand T, A Chandrasekaran, S Kuttalam, T Raguchander, V Prakasam and R Samiyappan. 2007. Association of some plant defense enzyme activities with systemic resistance to early leaf blight and leaf spot induced in tomato plants by azoxystrobin and Pseudomonas fluorescens. Journal of Plant Interactions 2: 233-244.

9. Angelova Z, S Georgiev and W Roos. 2006. Elicitation of Plants. Biotechnology \& Biotechnological Equipment 20: 72-83.

10. Ash GJ and RG Rees. 1994. Effect of post-inoculation temperature and light-intensity on expression of resistance to stripe rust in some Australian wheat cultivars. Australian Journal of Agricultural Research 45: 1379-1386.

11. Basandrai AK, A Mehta, VK Rathee, D Basandrai and BK Sharma. 2020. Efficacy of fungicides in 
managing yellow rust of wheat. Journal of Cereal Research 12(2): 103-108.

12. Batista ACM, FES Neto and WS Paiva. 2018. Review of fungal chitosan: past, present and perspectives in Brazil. Polimeros 28(3):275-283.

13. Bektas Y and T Eulgem. 2015. Synthetic plant defense elicitors. Frontiers in Plant Science 5:804. doi: 10.3389/fpls.2014.00804

14. Belanger RR, N Benhamou and JG Menzies. 2003. Cytological evidence of an active role of silicon in wheat resistance to powdery mildew (Blumeria graminisf. sp. tritici). Phytopathology 93:402-412.

15. Bellameche F, C Pedrazzini, B Mauch-Mani, and F Mascher. 2020. Efficiency of biological and chemical inducers for controlling Septoria tritici leaf blotch (STB) on wheat (Triticum aestivum L.). European Journal of Plant Pathology 158:99-109.

16. Bishnoi SK, X He, RM Phuke, PL Kashyap, A Alakonya, V Chhokkar, RP Singh and PK Singh. 2020. Karnal bunt: A re-emerging old foe of wheat. Frontiers in Plant Science 11:1486.

17. Bruce JA, LE Smart, ANE Birch. Bruce T J, LE Smart, ANE Birch, VC Blok, K MacKenzie,E Guerrieri, and J Ton. 2017. Prospects for plant defence activators and biocontrol in IPM-Concepts and lessons learnt so far. Crop Protection 97: 128-34.

18. Bruce TJ. 2010. Tackling the threat to food security caused by crop pests in the new millennium. Food Security 2: 133-141.

19. Burkhanova GF, SV Veselova, AV Sorokan, DK Blagova, TV Nuzhnaya, and IV Maksimov. 2017. Strains of Bacillus ssp. regulate wheat resistance to Septoria nodorum Berk. Applied Biochemistry and Microbiology 53: 346-352.

20. Buzón-Durán L, J Martín-GiljJL Marcos-Robles, A Fombellida-Villafruela, E Pérez-Lebeña, and $\mathrm{P}$ Martín-Ramos. 2020. Antifungal activity of chitosan oligomers-amino acid conjugate complexes against Fusarium culmorum in Spelt (Triticum spelta L.). Agronomy 10:1427.

21. Carmona MA, FJ Sautua, PE Grijalba, M Cassina and O Pérez-Hernández. 2018. Effect of potassium and manganese phosphites in the control of Pythium damping-off in soybean: a feasible alternative to fungicide seed treatments. Pest Management Sciences 74: 366-374.

22. Chain F, C Côté-Beaulieu, F Belzile, J Menzies and R Bélanger. 2009. A comprehensive transcriptomic analysis of the effect of silicon on wheat plants under control and pathogen stress conditions. Molecular Plant-Microbe Interactions 22:1323-1330.

23. Choudhary DK and BN Johri. 2009. Interactions of Bacillus spp. and plants - with special reference to induced systemic resistance (ISR). Microbiological Research 164: 493-513.

24. Conrath U. 2006. Systemic Acquired Resistance. Plant Signaling and Behavior 1: 179-184.

25. Cordo CA, CI Monaco, CI Segarra, MR Simon, AY Mansilla, AE Perelló and RD Conde. 2007. Trichoderma spp. as elicitors of wheat plant defense responses against Septoria tritici. Biocontrol Science and Technology 17(7): 687-698.

26. Cortes-Barco AM, PH Goodwin and T Hsiang. 2010. Comparison of induced resistance activated by benzothiadiazole, $(2 \mathrm{R}, 3 \mathrm{R})$-butanediol and an isoparaffin mixture against anthracnose of Nicotiana benthamiana. Plant Pathology 59(4): 643-653.

27. Cruz MFA, APC Diniz, FA Rodrigues and EG Barros. 2011. Foliar application of products on the reduction of wheat blast severity. Tropical Plant Pathology 36: 424-428.

28. Deliopoulos T, PS Kettlewell and MC Hare. 2010. Fungal disease suppression by inorganic salts: A review. Crop Protection 29: 1059-1075.

29. Devi HM, S Mahapatra, and S Das. 2019. Management of spot blotch of wheat using inducer chemicals under field conditions. Journal of Cereal Research 11 (2):152 -158.

30. Dewen Q, D Yijie, Z Yi, L Shupeng, and S Fachao. 2017. Plant Immunity inducer development and application. Molecular Plant-Microbe Interactions 30:355-360.

31. Domiciano GP, FA Rodrigues, AMN Guerra and FXR Vale. 2013. Infection process of Bipolaris sorokiniana on wheat leaves is affected by silicon. Tropical Plant Pathology 38: 258-263. 
32. Domiciano GP, FA Rodrigues, FXR Vale , MSX Filha, WR Moreira, CCL Andrade and SC Pereira. 2010. Wheat resistance to spot blotch potentiated by silicon. Journal of Phytopathology 158: 334-343.

33. Draz IS, AA Elkhwaga, AA Elzaawely HM ElZahaby, and AA Ismail 2019. Application of plant extracts as inducers to challenge leaf rust of wheat. Egyptian Journal of Biological Pest Control 29: 6.

34. Drennan PM, MT Smith Goldsworthy and J van Staden. 1993. The occurrence of trehalose in the leaves of the desiccation-tolerant angiosperm Myrothamnus flabellifolius welw. Journal of Plant Physiology 142: 493-496.

35. Duan Z, G Lv, C Shen Q Li, Z Qin and J Niu. 2014. The role of jasmonic acid signalling in wheat (Triticum aestivum L.) powdery mildew resistance reaction. European Journal of Plant Pathology 140:169183.

36. Durrant WE and X Dong. 2004. Systemic acquired resistance. Annual Review of Phytopathology 42: 185-209.

37. Dutt S, D Pandey and A Kumar. 2011. Jasmonate signal induced expression of cystatin genes for providing resistance against Karnal bunt in wheat. Plant Signaling and Behavior 6: 821-830.

38. El-Sharkawy HHA, YM Rashad and SA Ibrahim. 2018. Biocontrol of stem rust disease of wheat using arbuscular mycorrhizal fungi and Trichoderma spp. Physiological and Molecular Plant Pathology 103:84-91

39. Erbs G. and MA Newman. 2003. The role of lipopolysaccharides in induction of plant defence responses. Molecular Plant Pathology 4: 421-425.

40. Eyles A, P Bonello, R Ganley, and C Mohammed. 2010. Induced resistance to pests and pathogens in trees. New Phytology 185(4):893-908. doi: 10.1111/j.1469-8137.2009.03127.x.

41. Figueroa M, KE Hammond-Kosack and PS Solomon. 2018. A review of wheat diseases-a field perspective. Molecular Plant Pathology 19:1523-1536.

42. Filha MSX, FA Rodrigues and GP Domiciano. 2011. Wheat resistance to leaf blast mediated by silicon. Australasian Plant Pathology 40: 28-38.
Resistance inducers for wheat protection from fungal pathogens

43. Fobert PR and C Després. 2005. Redox control of systemic acquired resistance. Current Opinion in Plant Biology 8(4):378-382.

44. Forster H, JE Adaskaveg, DH Kim and ME Stanghellini. 1998. Effect of phosphite on tomato and pepper plants and on susceptibility of pepper to Phytophthora root and crown rot in hydroponic culture. Plant Disease 82:1165-1170.

45. Francesconi S, B Steiner, H Buerstmayr, M Lemmens, M Sulyok and GM Balestra. 2020. Chitosan hydrochloride decreases fusarium graminearum growth and virulence and boosts growth, development and systemic acquired resistance in two durum wheat genotypes. Molecules 25:4752.

46. Gardner SN, AA Agrawal, J Gressel and M Mangel. 1999. Strategies to delay the evolution of resistance in pests: dose rotations and induced plant defenses. Aspects of Applied Biology 53:189-196.

47. Gong AD, HP Li and QS Yuan. 2015. Antagonistic mechanism of iturin A and plipastatin A from Bacillus amyloliquefaciens S76-3 from wheat spikes against Fusarium graminearum. PLoS ONE 10: e0116871.

48. Görlach J, S Voirath and G Knauf-Beiter. 1996. Benzothiadiazole, a novel class of inducers of systemic acquired resistance, activates gene expression and disease resistance in wheat. The Plant Cell 8: 629-643.

49. Goyal A and R Prasad. 2010. Some important fungal diseases and wheat production. In: Management of fungal plant pathogens (eds A. Arya and A.E. Perelló). CAB International pp. 362-373. 10.1079/9781845936037.0362

50. Grant M and C Lamb. 2006. Systemic immunity. Current Opinion in Plant Biology 9:414-420.

51. Griffey CA, MK Das and EL Stromberg. 1993. Effectiveness of adult plant resistance in reducing grain yield loss to powdery mildew in winter wheat. Plant Disease 77: 618-622.

52. Guével MH, JG Menzies and RR Bélanger. 2007. Effect of root and foliar applications of soluble silicon on powdery mildew control and growth of 
wheat plants. European Journal of Plant Pathology 119: 429-436.

53. Gunupuru LR, JS Patel, MW Sumarah, JB Renaud, EG Mantin and B Prithiviraj. 2019. A plant biostimulant made from the marine brown algae Ascophyllum nodosum and chitosan reduce Fusarium head blight and mycotoxin contamination in wheat. PLoS One 14(9):e0220562.

54. Gupta N, N Batra, and SC Bhardwaj. 2017. Wheat rust research - Status, efforts and way ahead. Journal of Wheat Research 9 (2):72-86.

55. Heier T, SKJain, KH Kogel and J Pons-Kühnemann. 2005. Influence of $\mathrm{N}$-fertilization and fungicide strategies on Fusarium head blight severity and mycotoxin content in winter wheat. Journal of Phytopathology 153(9): 551-557.

56. Heil M and RM Bostock. 2002. Induced systemic resistance (ISR) against pathogens in the context of induced plant defences. Annals of Botany 89(5): 503-512.

57. Heil M, A Hilpert, W Kaiser and KE Linsenmair. 2000. Reduced growth and seed set following chemical induction of pathogen defence: Does systemic acquired resistance (SAR) incur allocation costs? Journal of Ecology 88: 645-654.

58. Herms DA and WJ Mattson. 1992. The dilemma of plants to grow or defend. Quarterly Review of Biology 67:283-335.

59. Hoffland E, J Hakulinem and JA Van Pelt. 1996. Comparison of systemic resistance induced by avirulent and nonpathogenic Pseudomonas species. Phytopathology 86:757-762.

60. Hofgaard IS, A Ergon, LA Wanner and AM Tronsmo. 2005. The effect of chitosan and Bion on resistance to pink snow mould in perennial ryegrass and winter wheat. Journal of Phytopathology 153: 108-119.

61. Islam W, M Tayyab, F Khalil, Z Hua, Z Huang and HTH Chen. 2020. Silicon-mediated plant defense against pathogens and insect pests. Pesticide Biochemistry and Physiology 168:104641.

62. Jamiołkowska A. 2020. Natural compounds as elicitors of plant resistance against diseases and new biocontrol strategies. Agronomy 10:173. https://doi. org/10.3390/agronomy 10020173.

63. Jasrotia P, PL Kashyap, AK Bhardwaj, S Kumar and GP Singh. 2018. Scope and applications of nanotechnology for wheat production: A review of recent advances. Wheat and Barley Research 10: 137-150.

64. Jayaraj J, S Muthukrishnan and G Liang. 2004. Jasmonic acid and salicylic acid induce accumulation of $\beta$-1, 3-glucanase and thaumatin-like proteins in wheat and enhance resistance against Stagonospora nodorum. Biologia Plantarum 48: 425-430.

65. Jindal MM, I Sharma, and NS Bains. 2012. Losses due to stripe rust caused by Puccinia striiformis in different varieties of wheat. Journal of Wheat Research 4 (2): 33-36.

66. Jørgensen LN, BJM Secher, JE Olesen and J Mortensen. 1997. Need for fungicide treatments when varying agricultural parameters. Aspects of Applied Biology 50: 285-292.

67. Joshi AK, S Kumar, R Chand, and G Ortiz-Ferrara. 2004. Inheritance of resistance to spot blotch pathogen caused by Bipolaris sorokiniana in spring wheat. Plant Breeding 123: 213-219.

68. Karban R and IT Baldwin. 1997. Induced responses to herbivory, Chicago Press, Ill, USA.

69. Kashyap PL and JS Dhiman 2009. Induction of resistance in cauliflower against Alternaria blight using potassium and phosphonic salts. The Asian and Australasian Journal of Plant Science and Biotechnology 3: 66-70.

70. Kashyap PL, AK Srivastava, SP Tiwari and S Kumar. 2018b. Microbes for Climate Resilient Agriculture, John Wiley and Sons. pp. 376.

71. Kashyap PL, MK Solanki, P Kushwaha, S Kumar and AK Srivastava. 2020c. Biocontrol potential of salt-tolerant Trichoderma and Hypocrea isolates for the management of tomato root rot under saline environment. Journal of Soil Science and Plant Nutrition 20(1):160-176.

72. Kashyap PL, P Rai, AK Srivastava and S Kumar. 2017. Trichoderma for climate resilient agriculture. World Journal of Microbiology and Biotechnology 33: 155. 
73. Kashyap PL, S Kaur and PPS Pannu 2018a. Induction of systemic tolerance to Tilletia indica in wheat by plant defence activators. Archives of Phytopathology and Plant Protection 51: 1-13.

74. Kashyap PL, S Kumar, P Jasrotia, DP Singh, and GP Singh. 2020a. Nanotechnology in Wheat Production and Protection. In: Dasgupta N., Ranjan S., Lichtfouse E. (eds) Environmental Nanotechnology Volume 4. Environmental Chemistry for a Sustainable World, vol 32. Springer, Cham. pp165-194.

75. Kashyap PL, S Kumar, RS Kumar, A Sharma, P Jasrotia, DP Singh, and GP Singh. 2020b. Molecular diagnostic assay for rapid detection of flag smut fungus (Urocystis agropyri) in wheat plants and field soil. Frontiers in Plant Science 11: 1039.

76. Kashyap PL, X Xiang and P Heiden. 2015. Chitosan nanoparticle based delivery systems for sustainable agriculture. International Journal of Biological Macromolecules 77:36-51.

77. Kempf HJ and G Wolf. 1989. Erwinia herbicola as a biocontrol agent of Fusarium culmorum and Puccinia recondita f. sp. tritici on wheat. Phytopathology 79: 990-994.

78. Khan JB, S Singh, C Kanchan, PK Gupta, and J Kumar. 2021. Screening and evaluation of wheat varieties against powdery mildew (Blumeria graminis f. sp. tritici) under field conditions. Journal of Cereal Research 13(1): 94-97.

79. Khan MR and FM Doohan. 2009 Comparison of the efficacy of chitosan with that of a fluorescent pseudomonad for the control of Fusarium head blight disease of cereals and associated mycotoxin contamination of grain. Biological Control 48:48-54.

80. Kheiri A, SA Moosawi Jorf, A Malihipour, H Saremi and M Nikkhah. 2016. Application of chitosan and chitosan nanoparticles for the control of Fusarium head blight of wheat (Fusarium graminearum) in vitro and greenhouse. International Journal of Biological Macromolecules 93:1261-1272.

81. Khong NG, B Randoux and CH Tayeh. 2012. Induction of resistance in wheat against powdery mildew by bacterial cyclic lipopeptides. Communications in Agricultural and Applied Biological Sciences 77: 39-51.
82. Khong NG, B Randoux and J Deravel. 2013. Induction of resistance in wheat by bacterial cyclic lipopeptides. Communications in Agricultural and Applied Biological Sciences 78: 479-487.

83. Kilic-Ekici O and GY Yuen. 2003. Induced resistance as a mechanism of biological control by Lysobacter enzymogenes strain C3. Phytopathology 93: 1103-1110.

84. Kim YC, YH Kim and YH Lee. 2013. $\beta$-Amino-nbutyric Acid Regulates Seedling Growth and Disease Resistance of Kimchi Cabbage. The Plant Pathology Journal 29: 305-316.

85. Kumar S, PL Kashyap, MS Saharan, I Singh, P Jasrotia, DP Singh, and GP Singh. 2018. Difenoconazole: a new seed dressing molecule for effective management of flag smut (Urocystis agropyri) of wheat. Journal of Cereal Research 11(1):37-40.

86. Kumar S, S Mahapatra, S Chakraborty and S Mukharjee. 2021. Effect of abiotic stresses and mitigation strategy associated with their tolerance in wheat. Journal of Cereal Research 13: 16-37.

87. Kumaran VK, S Murugasamy, J Paramasivan, $\mathrm{P}$ Prasad, S Kumar, S C Bhardwaj, G Murugan, N Rebekah, S Paneer and J Peter. 2021. Marker assisted pyramiding of stem rust, leaf rust and powdery mildew resistance genes for durable resistance in wheat (Triticum aestivum L.). Journal of Cereal Research 13(1): 38-48.

88. Kushwaha P, PL Kashyap, AK Srivastava, and RK Tiwari. 2020. Plant growth promoting and antifungal activity in endophytic Bacillus strains from pearl millet (Pennisetum glaucum). Brazilian Journal of Microbiology 51(1):229-241.

89. Li Y, L Qiu and X Liu. 2020. Glycerol-induced powdery mildew resistance in wheat by regulating plant fatty acid metabolism, plant hormones crosstalk, and pathogenesis-related genes. International Journal of Molecular Sciences 21:673.

90. Li Y, N Song and C Zhao. 2016. Application of glycerol for induced powdery mildew resistance in Triticum aestivum L. Frontiers in Physiology 7: 413.

91. Llorens E, P García-Agustín and L Lapeña. 2017. Advances in induced resistance by natural 
compounds: towards new options for woody crop protection. Scientia Agricola 74: 90-100.

92. Lovatt CJ and RL Mikkelsen. 2006. Phosphite fertilizers: What are they? Can you use them? What can they do? Better Crops 90: 11-13.

93. Luo Y, X Liu and W Li. 2021. Exogenouslysuppliedtrehalose inhibits the growth of wheat seedlings under high temperature by affecting plant hormone levels and cell cycle processes. Plant Signaling E Behavior 16:e 1907043.

94. Lyon G. and A Newton. 2007. Agents that can elicit induced resistance. In: Induced resistance for plant defence: A sustainable approach to crop protection. Blackwell Publishing, Oxford. pp. 9-29.

95. Mahapatra S and S Das. 2013. Efficacy of different fungicides against spot blotch of wheat in terai region of West Bengal. Journal of Wheat Research 5 (2):18-21.

96. Maluin FN and M Hussein. 2020. Chitosan-based agronanochemicals as a sustainable alternative in crop protection. Molecules 25:1611

97. Mandal MK, D Pandey, S Purwar, US Singh and A Kumar. 2006. Influence of jasmonic acid as potential activator of induced resistance against Karnal bunt in developing spikes of wheat. Journal of Biosciences 31:601-607.

98. Mateo A, P Mühlenbock, and C Rustérucci. 2004. LESION SIMULATING DISEASE 1 is required for acclimation to conditions that promote excess excitation energy. Plant Physiology 136: 2818-2830.

99. Maurhofer M, C Hase, P Meuwly, JP Metraux, and G Defago. 1994. Induction of systemic resistance of tobacco to tobacco necrosis virus by the rootcolonizing Pseudomonas fluorescens strain CHAO: Influence of the gacA gene and of pyoverdine production. Phytopathology 84: 139-146

100. Mehta YR. 2014. Wheat diseases and their management. Springer International Publishing Switzerland, pp256.

101. Mejri S, A Siah and F Coutte. 2017. Biocontrol of the wheat pathogen Zymoseptoria tritici using cyclic lipopeptides from Bacillus subtilis. Environmental Science and Pollution Research.
102. Mire GL, A Siah and MN Brisset. 2018. Surfactin protects wheat against Zymoseptoria tritici and activates both salicylic acid- and jasmonic aciddependent defense responses. Agriculture 8:11.

103. Motallebi P, V Niknam and H Ebrahimzadeh. 2015. The effect of methyl jasmonate on enzyme activities in wheat genotypes infected by the crown and root rot pathogen Fusarium culmorum. Acta Physiologiae Plantarum 37: 237.

104. Muchembled J, A Lounes-Hadj Sahraoui, A Grandmoujin-Ferjani and M Sancholle. 2006. Changes in lipid composition of Blumeria graminis f. sp. tritici conidia produced on wheat leaves treated with heptanoyl salicylic acid. Phytochemistry 67:1104-1109.

105. Muhae-Ud-Din G, D Chen and T Liu. 2020. Methyl jasmonate and salicylic acid contribute to the control of Tilletia controversa Kühn, causal agent of wheat dwarf bunt. Scientific Reports 10:19175

106. Naguib DM. 2018. Control of Fusarium wilt in wheat seedlings by grain priming with defensin-like protein. Egyptian Journal of Biological Pest Control 28:68. https://doi.org/10.1186/s41938-018-0073-9

107. Newton A, D Guy,R Gaunt and W Thomas. 2000. The effect of powdery mildew inoculum pressure and fertilizer levels on disease tolerance in spring barley. Zeitschrift fur Pflanzenkrankheiten und Pflanzenschutz 107: 67-73.

108. Newton AC, IK Toth,P Neave and LJ Hyman. 2004. Bacterial inoculum from a previous crop affects fungal disease development on subsequent non-host crops. New Phytologist 63: 133-138.

109. Newton AC, JS Swanston and D Guy. 2004. Enhanced durability and utility of genes for resistance by deployment in cultivar mixtures. In: Proceedings Molecular Plant-Microbe Interactions XI, (St Petersburg), pp 240-243.

110. Oliveira MDM., CMR Varanda and MRF Félix. 2016. Induced resistance during the interaction pathogen $x$ plant and the use of resistance inducers. Phytochemistry Letters 15: 152-158.

111. Ons L, D Bylemans, K Thevissen and BPA Cammue. 2020. Combining biocontrol agents with chemical fungicides for integrated plant fungal disease 
control. Microorganisms 8(12):1930. doi:10.3390/ microorganisms 8121930

112. Ortmann I. and BM Moerschbacher. 2006. Spent growth medium of Pantoea agglomerans primes wheat suspension cells for augmented accumulation of hydrogen peroxide and enhanced peroxidase activity upon elicitation. Planta 224: 963-970.

113. Orzali L, C Forni and L Riccioni. 2014. Effect of chitosan seed treatment as elicitor of resistance to Fusarium graminearum in wheat. Seed Science and Technology 42:132-149.

114. Pagán I and F García-Arenal. 2018. Tolerance to plant pathogens: Theory and experimental evidence. International Journal of Molecular Sciences 19:810. doi: 10.3390/ijms 19030810 .

115. Pagani APS, AC Dianese and AC Café-Filho. 2014. Management of wheat blast with synthetic fungicides, partial resistance and silicate and phosphite minerals. Phytoparasitica 42: 609-617

116. Park RF. 2007. Stem rust of wheat in Australia. Australian Journal of Agricultural Research 58:558-566.

117. Pasquer F, E Isidore, J Zarn and B Keller. 2005. Specific patterns of changes in wheat gene expression after treatment with three antifungal compounds. Plant Molecular Biology 57: 693-707.

118. Phuong LT, L Zhao., AN Fitrianti, H Matsui, Y Noutoshi, M Yamamoto, Y Ichinose, T Shiraishi and K Toyoda. 2020. The plant activator saccharin induces resistance to wheat powdery mildew by activating multiple defense-related genes. Journal of General Plant Pathology 86(2):107-113. https://doi. org/10.1007/s10327-019-00900-7

119. Pieterse CMJ, C Zamioudis, RL Berendsen. 2014. Induced systemic resistance by beneficial microbes. Annual Review of Phytopathology 52: 347-75.

120. Puyam A, PPS Pannu and S Bisht. 2019. Management of bakanae disease using induced resistance and QTL for resistance breeding. Journal of Cereal Research 11(3):199-205.

121. Qi PF, M Balcerzak, H Rocheleau, W Leung, YM Wei, YL Zheng and T Ouellet. 2016. Jasmonic acid and abscisic acid play important roles in hostpathogen interaction between Fusarium graminearum
Resistance inducers for wheat protection from fungal pathogens

and wheat during the early stages of Fusarium head blight. Physiological and Molecular Plant Pathology 93: 39-48.

122. Raafat D and HG Sahl. 2009. Chitosan and its antimicrobial potential--a critical literature survey. Microbial Biotechnology 2:186-201.

123. Rai S, PL Kashyap, S Kumar, AK Srivastava and W Ramteke. 2016a. Identification, characterization and phylogenetic analysis of antifungal Trichoderma from tomato rhizosphere. SpringerPlus 5:1939.

124. Rai S, PL Kashyap, S Kumar AK Srivastava and W Ramteke. 2016b. Comparative analysis of microsatellites in five different antagonistic Trichoderma species for diversity assessment. World Journal of Microbiology and Biotechnology 32:8.

125. Ranf S. 2016. Immune Sensing of Lipopolysaccharide in Plants and Animals: Same but Different. PLoS Pathogens 12: e1005596.

126. Reddy MVB, J Arul,P Angers and L Couture. 1999. Chitosan treatment of wheat seeds induces resistance to Fusarium graminearum and improves seed quality. Journal of Agricultural and Food Chemistry 47: 1208-1216.

127. Reignault P, A Cogan and J Muchembled. 2001. Trehalose induces resistance to powdery mildew in wheat. New Phytologist 149: 519-529.

128. Reignault P, B Randoux, D Renard, J Sanssen and R Durand. 2004. In: Defence responses activated by resistance inducers and natural compounds during the wheat/powdery mildew compatible interaction. Workshop on Resistance of cereals to biotic stress. IHAR Radzików, Poland. pp 47-51.

129. Remus-Borel W, JG Menzies, and RR Belanger RR. 2005. Silicon induces antifungal compounds in powdery mildew-infected wheat. Physiological and Molecular Plant Pathology 66(3): 108-115.

130. Reuveni M. 1997. Post-infection applications of $\mathrm{K}_{3} \mathrm{PO}_{3}$, phosphorous acid and dimethomorph inhibit development of downy mildew caused by Plasmopara viticola on grapes. Journal of Small Fruit and Viticulture 5: 27-38.

131. Rodgers-Gray BS and MW Shaw. 2004. Effects of straw and silicon soil amendments on some foliar 
and stem-base diseases in pot-grown winter wheat. Plant Pathology 53:733-740.

132. Rouget C. 1859. Des substances anlylacees dans le tissu des animaux specialement les urticules (Chitine). Comptes Rendus 48:792-795.

133. Sadak MS. 2019. Physiological role of trehalose on enhancing salinity tolerance of wheat plant. Bulletin of the National Research Centre 43: 53. https://doi. org/10.1186/s42269-019-0098-6

134. Sakr N. 2016. Silicon control of bacterial and viral diseases in plants. Journal of Plant Protection Research 56: 331-336.

135. Samain E, T Aussenac and S Selim. 2019. The Effect of plant genotype, growth stage, and Mycosphaerella graminicola strains on the efficiency and durability of wheat-induced resistance by Paenibacillus sp. Strain B2. Frontiers in Plant Science 10:587. doi: 10.3389/ fpls.2019.00587

136. Samain E, D Tuinenc,P Jeandetd,T Aussenace and S Selima. 2017. Biological control of Septoria leaf blotch and growth promotion in wheat by Paenibacillus sp. strain B2 and Curtobacterium plantarum strain EDS. Biological Control 114:87-96.

137. Sandroni, M, E Liljeroth, T Mulugeta and E Alexandersson. 2020. Plant resistance inducers (PRIs): perspectives for future disease management in the field. $C A B$ Reviews 15:1-10.

138. Santos HAA, MD Pria, OC Silva, and LLM Mio. 2011. Control of wheat diseases using phosphites and acibenzolar-s-methyl alone or associated with piraclostrobina + epoxiconazole. Semina: Ciências Agrárias 32:433-442.

139. Selvakumar R, MS Saharan, S Kumar, and I Sharma. 2015. Efficacy of fungicides as seed treatment and foliar spraying for management of leaf blight (Bipolaris sorokiniana) in wheat (Triticum aestivum L.). Journal of Wheat Research 7(2): 14-18

140. Sharma A, V Kumar, B Shahzad, M Tanveer, GPS Sidhu, N Handa, SK Kohli, P Yadav, AS Bali, RD Parihar, OI Dar, K Singh, S Jasrotia, P Bakshi, M Ramakrishnan, S Kumar, R Bhardwaj and AK Thukral. 2019. Worldwide pesticide usage and its impacts on ecosystem. SN Applied Sciences 1:1446. https://doi.org/10.1007/s42452-019-1485-1
141. Silva JM, MBCL Medeiros, JTC Oliveira, EV Medeiros, CM Souza-Motta and KA Moreira. 2018. Resistance inducers and biochemical mechanisms in the control anthracnosis on cowpea. Ciencia $e$ Investigación Agraria 45: 290-300

142. Silva WLD, MFA Cruz, AA Fortunato, and F Fodrigues. 2015. Histochemical aspects of wheat resistance to leaf blast mediated by silicon. Scientia Agricola 72: 322-327.

143. Singh DP, S Kumar, and PL Kashyap. 2020. Disease spectrum in wheat and Barley under different agroecological conditions in India and management strategies. In: Diseases of Field Crops Diagnosis and Management, 2-Volume Set: Volume 1: Cereals, Small Millets, and Fiber Crops Volume 2: Pulses, Oil Seeds, Narcotics, and Sugar Crops (eds JN Srivastava,; AK Singh), Apple Academic press, pp 57-79.

144. Singh RK, DP Kumar, P Singh, MK Solanki, S Srivastava, PL Kashyap, S Kumar, AK Srivastava, PK Singhal and DK Arora. 2014. Multifarious plant growth promoting characteristics of chickpea rhizosphere associated Bacilli help to suppress soilborne pathogens. Plant Growth Regulation 73(1): 91-101.

145. Singh RP and PN Jha. 2017. The PGPR Stenotrophomonas maltophilia SBP-9 augments resistance against biotic and abiotic stress in wheat plants. Frontiers in Microbiology 8: 1945.

146. Singh UB, D Malviya, S Singh, M Imran, N Pathak, M Alam, JP Rai, RK Singh, BK Sarma, PK Sharma and AK Sharma. 2016. Compatible salttolerant rhizosphere microbe-mediated induction of phenylpropanoid cascade and induced systemic responses against Bipolaris sorokiniana (Sacc.) Shoemaker causing spot blotch disease in wheat. (Triticum aestivum L.). Applied Soil Ecology 108: 300306.

147. Solanki MK, N Singh, RK Singh, P Singh, AK Srivastava, S Kumar, PL Kashyap and DK Arora. 2011. Plant defense activation and management of tomato root rot by a chitin-fortified Trichodermal Hypocrea formulation. Phytoparasitica 39: 471-481. 
148. Solanki MK, RK Singh, S Srivastava, S Kumar, PL Kashyap and AK Srivastava 2015. Characterization of antagonistic-potential of two Bacillus strains and their biocontrol activity against Rhizoctonia solani in tomato. Journal of Basic Microbiology 55: 82-90.

149. Solanki MK, S Kumar, AK Pandey, S Srivastava, RK Singh , PL Kashyap , AK Srivastava and DK Arora. 2012. Diversity and antagonistic potential of Bacillus spp. associated to the rhizosphere of tomato for the management of Rhizoctonia solani. Biocontrol Science and Technology 22:203-217.

150. Sousa RS, FA Rodrigues, DA Schurt, NFA Souza and MFA Cruz. 2013. Cytological aspects of the infection process of Pyricularia oryzae on leaves of wheat plants supplied with silicon. Tropical Plant Pathology 38: 472-477.

151. Srivastava AK, RN Singh,S Kumar, PL Kashyap and DK Arora. 2012. Growth promotion and management of Alternaria leaf spot in chilli by Trichoderma harzianum. International Journal of Innovative Horticulture 1: 158-163.

152. Stadnik MJ and H Buchenauer. 1999. Control of wheat diseases by a benzothiadiazole-derivative and modern fungicides. Journal of Plant Diseases and Protection 106: 466-475.

153. Stocco MC, AY Mansilla and CI Mónaco. 2015. Native isolates of Trichoderma harzianum inducting resistance to Zymoseptoria tritici on wheat plants. Boletín de la Sociedad Argentina de Botánica 50: 291-301.

154. Takenaka S, Z Nishio and Y Nakamura. 2003. Induction of defense reactions in sugar beet and wheat by treatment with cell wall protein fractions from the mycoparasite Pythium oligandrum. Phytopathology 93:1228-1232.

155. Tayeh C, B Randoux, D Vincent, N Bourdon and P Reignault. 2014. Exogenous trehalose induces defenses in wheat before and during a biotic stress caused by powdery mildew. Phytopathology 104: 293-305.

156. Thabet M. 2008. Induction of resistance in wheat plants against leaf rust caused by Puccinia triciana. Ain Shams University, Faculty of Agriculture, Egypt. M.Sc. Thesis. pp.122.
157. Thakur M and BS Sohal. 2013. Role of Elicitors in inducing resistance in plants against pathogen infection: A Review. ISRN Biochemistry 2013:762412.

158. Tian D, MB Traw, JQ Chen, M Kreitman and J Bergelson. 2003. Fitness costs of R-gene-mediated resistance in Arabidopsis thaliana. Nature 423:74-77.

159. Van der Plank JE 1968. In: Disease resistance in plants. Academic Press, London New York.

160. van Loon LC, PAHM Bakker and CMJ Pieterse. 1998. Systemic resistance induced by rhizosphere bacteria. Annual Review of Phytopathology 36: 453-483.

161. Věchet L and B Šerá. 2015 Effectiveness of both synthetic compounds and biological extracts against powdery mildew (Blumeria graminis $\mathrm{f}$. sp. tritici) on winter wheat. Agrociencia 49: 77-85

162. Walters DR, AC Newton, and GD Lyon. 2005. Induced resistance: Helping plants to help themselves. Biologist 52: 28-33.

163. Walters DR, J Ratsep and ND Havis, 2013. Controlling crop diseases using induced resistance: challenges for the future. Journal of Experimental Botany 64: 1263-1280.

164. Wang M, L Gao and S Dong. 2017. Role of silicon on plant-pathogen interactions. Frontiers in Plant Science 8: 701.

165. Wäspi U, D Blanc, T Winkler, P Ruedi and R Dudler. 1998. Syringolin, a novel peptide elicitor from Pseudomonas syringae pv. syringae that induces resistance to Pyricularia oryzae in rice. Molecular Plant-Microbe Interactions 11: 727-733.

166. Wäspi U, P Schweizer and R Dudler. 2001. Syringolin reprograms wheat to undergo hypersensitive cell death in a compatible interaction with powdery mildew. The Plant Cell 13:153-161.

167. Wiesel L, AC Newton and I Elliott. 2014. Molecular effects of resistance elicitors from biological origin and their potential for crop protection. Frontiers in Plant Science 5:655.

168. Xing K, X Zhu, X Peng and S Qin. 2015. Chitosan antimicrobial and eliciting properties for pest control in agriculture: A review. Agronomy for Sustainable Development 35:569-588. 
169. Yarullina LG, AR Akhatova and LM Yarullina. 2018. Effect of Salicylic and jasmonic acids on the content of hydrogen peroxide and transcriptional activity of the genes encoding defense proteins in wheat plants infected with Tilletia caries (DC.) Tull. Russian Journal of Plant Physiology 65:412-418.

170. Yassin M, J Ton, SA Rolfe, TA Valentine, M Cromey, N Holdend and AC Newton. 2021. The rise, fall and resurrection of chemical-induced resistance agents. Pest Management Science. DOI 10.1002/ps.6370

171. Yogita K, S Madan, B Rani, K Reena, and R Munjal. 2015. Trehalose mitigates heat stress-induced damages in wheat seedlings. Journal of Wheat Research 7(1):74-78.

172. Zhang S, DA Schisler, MJ Boehm and PJ Slininger. 2007. Utilization of chemical inducers of resistance and Cryptococcus flavescens $\mathrm{OH} 182.9$ to reduce Fusarium head blight under greenhouse conditions. Biological Control 42:308-315.

173. Zhou F, FLH Menke and K Yoshioka. 2004. High humidity suppresses ssi4-mediated cell death and disease resistance upstream of MAP kinase activation, $\mathrm{H}_{2} \mathrm{O}_{2}$ production and defense gene expression. The Plant Journal 39: 920-932.

174. Rios JA, FA Rodrigues, D Debona and LC Silva. 2014. Photosynthetic gas exchange in leaves of wheat plants supplied with silicon and infected with Pyricularia oryzae. Acta Physiologiae Plantarum 36:371-379. https://doi.org/10.1007/s11738-0131418-3

175. Somai-Jemmali L, M Magnin-Robert, B Randoux, A Siah, B Tisserant, P Halama, P Reignault and W Hamada. 2015. Ascorbic acid controls Mycosphaerella graminicola in bread and durum wheat through direct effect on the pathogen and indirect action via plant defence. Communications in Agricultural and Applied Biological Sciences 80(3):477490 .
176. Provance-Bowley M, JR Heckman and EF Durner. 2010. Calcium silicate suppresses powdery mildew and increases yield of field grown wheat. Soil Science Society of America Journal 74:1652-1661.

177. Kashyap PL, S Kumar, P Jasrotia, DP Singh and GP Singh. 2019. Nanosensors for plant disease diagnosis: Current understanding and future perspectives. Nanosensors for Plant Disease Diagnosis: Current Understanding and Future Perspectives. In: Pudake R., Chauhan N., Kole C. (eds) Nanoscience for Sustainable Agriculture. Springer, Cham. pp 189205. https://doi.org/10.1007/978-3-319-97852-9_9

178. Aucique-Perez CE, FA Rodrigues, WR Moreira and FM DaMatta. 2014. Leaf gas exchange and chlorophyll a fluorescence in wheat plants supplied with silicon and infected with Pyricularia oryzae. Phytopathology 104: 1431- 49.

179. Scala V, C Pietricola, V Farina, M Beccaccioli, S Zjalic, F Quaranta, M Fornara, M Zaccaria, B Momeni, M Reverberi and A. Iori. 2020. Tramesan elicits durum wheat defense against the septoria disease complex. Biomolecules 10(4):608. https://doi. org/10.3390/biom 10040608

180. Kessmann H, M Oostendrop, W Ruess, T Staub, W Kunz and J Ryals. 1996. Systemic activated resistance a new technology for plant disease control. Pesticide outlook 6:1-6. 